NBER WORKING PAPER SERIES

\title{
INFORMATION DIFFUSION EFFECTS IN \\ INDIVIDUAL INVESTORS' COMMON STOCK PURCHASES: COVET THY NEIGHBORS' INVESTMENT CHOICES
}

\author{
Zoran Ivković \\ Scott Weisbenner \\ Working Paper 10436 \\ http://www.nber.org/papers/w10436 \\ NATIONAL BUREAU OF ECONOMIC RESEARCH
1050 Massachusetts Avenue
Cambridge, MA 02138
April 2004
}

We extend our gratitude to an anonymous discount broker for providing the data on individual investors positions, trades, and demographics. Special thanks go to Terry Odean for his help in obtaining and understanding the data set. Both authors acknowledge the financial support from the College Research Board at the University of Illinois at Urbana-Champaign. We thank Jean Roth of the NBER for assistance with the 1990 Census data. Finally, we thank seminar participants at the Univesity of Florida and the University of Illinois for their comments and feedback. The views expressed herein are those of the authors and not necessarily those of the National Bureau of Economic Research.

(C2004 by Zoran Ivković and Scott Weisbenner. All rights reserved. Short sections of text, not to exceed two paragraphs, may be quoted without explicit permission provided that full credit, including $\mathbb{C}$ notice, is given to the source. 
Information Diffusion Effects in Individual Investors' Common Stock Purchases: Covet Thy Neighbors' Investment Choices

Zoran Ivković and Scott Weisbenner

NBER Working Paper No. 10436

April 2004

JEL No. D83, G11

\section{$\underline{\text { ABSTRACT }}$}

Using data on stock purchases individual investors made through a discount broker from 1991 to 1996, we study information diffusion effects - the relation between household investment choices and those made by their neighbors. A ten percentage point increase in neighbors' purchases of stocks from an industry is associated with a two percentage point increase in the household's own purchases of stocks from that industry, with the effect considerably larger for purchases of local stocks. The presence of information diffusion effects is robust to controls for potential inside information effects and to household fixed effects. Upon controlling for aggregate trading patterns, households' and neighbors' investment style preferences, and the industry composition of local firms, we attribute approximately one-third to one-half of the overall diffusion effect to word-of-mouth communication. Disentangling the overall diffusion effect suggests that the significant relation between our measures of information diffusion and subsequent industry-level returns appears to be driven by its word-of-mouth component.

Zoran Ivković

Department of Finance

University of Illinois

340 Wohlers Hall

1206 South Sixth Street

Champaign, IL 61820

ivkovich@uiuc.edu
Scott Weisbenner

Department of Finance

University of Illinois

340 Wohlers Hall

1206 South Sixth Street

Champaign, IL 61820

and NBER

weisbenn@uiuc.edu 
Although individual investors hold approximately one-half of the stock market in the U.S., relatively little is known about what governs their investment decisions. Generally, individual investors may choose to buy stocks for a variety of reasons ${ }^{1}$ and may consider a broad spectrum of information sources. In this paper we study information diffusion effects among individual investors - the relation between the investment choices made by an individual investor's neighborhood and the investor's own investment choices. Information diffusion effects among individual investors in the U.S. have received relatively little attention in the academic literature, probably because of the lack of detailed data. If present, such effects undoubtedly can affect individual investors' asset allocation decisions. Moreover, trades based on information diffusion might be sufficiently correlated and condensed in time to affect stock prices.

In the domain of institutional investors, Hong, Kubik, and Stein (2003) study word-ofmouth effects among mutual fund managers and find that “.... a manager is more likely to hold (or buy, or sell) a particular stock in any quarter if other managers in the same city are holding (or buying, or selling) that same stock." Similarly, individual investors may seek to reduce search costs and circumvent their lack of expertise by relying on word-of-mouth communication with those around them. Indeed, Hong, Kubik, and Stein (2004) present a model in which stock market participation may be influenced by social interaction. Such social interaction can serve as a mechanism for information exchange via "word-of-mouth" and/or "observational learning" (Banerjee (1992), Ellison and Fudenberg $(1993,1995)$ ).

Duflo and Saez $(2002,2003)$ present evidence of peer effects in a related contextretirement plans. They find that an employee's participation in retirement plans and choices within those plans are affected by participation decisions and choices made by other employees in the same department.

In the international arena, Feng and Seasholes (2004) present evidence of herding effects among individual investors who hold individual brokerage accounts in the People's Republic of China. A unique feature of their data (investors have to place trades only in the brokerage house in which they opened an account) enables Feng and Seasholes to disentangle word-of-mouth effects from common reaction to releases of public information. They find that common reaction to public information (trades placed across branches in the same region, local to the company),

\footnotetext{
${ }^{1}$ For a recent review see Barber, Odean, and Zhu (2003).
} 
rather than word-of-mouth effects (trades placed in the same branch), seems to be a primary determinant of herding in this context.

We study information diffusion effects among U.S. individual investors by using a detailed data set of common-stock investments 35,673 U.S. households made through a large discount brokerage in the period 1991 to 1996 . We pay attention to the overall magnitude of the effect, as well as to its heterogeneity across industries and across time. We also investigate whether high levels of information diffusion have predictive power for future industry-level returns. Moreover, we disentangle the diffusion among the influences of common preferences, structure of the local industry, and word-of-mouth effects. We find that disentangling the overall information diffusion effect suggests that the significant relation between diffusion and subsequent industry-level returns appears to be driven by its word-of-mouth component.

We find a strong information diffusion effect ("neighborhood effect"): a ten percentage point increase in purchases of stocks from an industry made by a household's neighbors is associated with a two percentage point increase in the household's own purchases of stocks from that industry. We pay particular attention to the differentiation between information diffusion effects related to local stocks (defined as companies headquartered within 50 miles from the household) and the effects related to non-local stocks. While the key neighborhood effectssimilarity in preferences, the impact of the structure of the local industry, and word-of-mouthcan prevail among the investments both local and non-local to the household, most of those effects will likely be far more pronounced among local investments because, as demonstrated for both professional money managers (Coval and Moskowitz, 2001) and individual investors (Ivković and Weisbenner, 2004), the flow of value-relevant information regarding local companies appears to be higher and of better quality than the comparable flow regarding remote, non-local companies.

Not surprisingly, we indeed find that information diffusion effects are considerably stronger for local purchases than for non-local ones. For example, if the neighborhood's allocation of local purchases to a particular industry increases by ten percentage points, a household tends to increase its own allocation of local purchases to the industry by a comparable amount. This result adds another dimension to the already documented high degrees of individual investors' locality, both in the U.S. (Ivković and Weisbenner (2004), Zhu (2002)) and abroad (Grinblatt and Keloharju (2001), Massa and Simonov (2003)): not only do investors tend 
disproportionately to invest locally, but there are also strong information diffusion effects in their neighborhood.

In an attempt to study the way information diffusion effects dissipate over time and space, we show that there is a relation between a household's own purchases and purchases made by the household's neighbors not only contemporaneously, but also with a lag of up to four quarters. As for space, we find that information diffusion effects wane fairly quickly beyond the distance of 50 miles; purchases by those residing 100 miles away have only one-tenth of the impact that purchases by the immediate neighbors (residing within 50 miles) have.

We further find that a household's sensitivity to neighbors' investment choices increases with the population of the household's community. Such diffusion in stock trading affects individual investors' asset allocation decisions. For example, although residents in larger metropolitan areas have substantially more diverse investment opportunities and tend to invest more in local stocks, we find that their local stock investments tend to remain just as concentrated as residents of less populated communities that have a significantly smaller pool of potential local investments. This tendency is consistent with the notion that residents in more populous geographic areas might be exposed to word-of-mouth effects to a higher degree than residents in less highly populated areas.

Our inquiry extends beyond establishing the existence of industry-level information diffusion effects, attributing them, and characterizing them; we also investigate whether the extent of information diffusion effects has predictive power for future industry-level returns. We find that, even after controlling for aggregate individual investors' trading activity (i.e., the buysell imbalance in that industry) and past industry-level performance, non-local information diffusion is positively associated with future industry returns: an increase in information diffusion equal to the interquartile range of the estimates of information diffusion across 322 industry-quarter observations is associated with a two to three percentage point increase in industry returns over the following year. Moreover, we buttress these results by presenting an explanation that relates the role of non-local diffusion with a gradual diffusion of value-relevant information from local investors to non-local ones, accompanied with appropriate trading patterns.

Finally, to disentangle the contributions of correlated preferences and the structure of the local economy to the observed correlation between individual investors stock purchases and 
those of their neighbors from "word-of-mouth" effects, we consider the households" own preferences (as revealed by the composition of their respective portfolios across industries at the beginning of each quarterly investment period), preferences of the households' respective neighborhoods (as revealed by the composition of the neighborhoods' aggregate portfolios), as well as the composition of local firms and workers by industry. We find that one-third to onehalf of the overall neighborhood effect among both local and non-local investments cannot be attributed to these sources. We regard the remaining portions of the neighborhood effect as a conservative lower bound on the impact of word-of-mouth communication effects on household trading decisions. Disentangling the overall information diffusion effect into word-of mouth communication and other diffusion effects yields further insight as to how correlated trading among individuals may influence stock prices. The significant relation between non-local diffusion and subsequent industry-level returns appears to be driven by the word-of-mouth component. This result is consistent with the hypothesis that word-of-mouth communication creates a more dynamic exchange of information that may lead to a ripple effect of further information dissemination, which in turn may eventually impact stock prices.

The remainder of this paper is organized as follows. Section I describes the data and summary statistics. We present our basic findings concerning information diffusion in Section II. Section III analyzes the dissipation of diffusion effects across time and space and explores the relation between diffusion effects and location. Section IV documents the heterogeneity of information diffusion across industries and across time and relates future industry-level returns to our estimates of information diffusion. We identify the contributions of correlated preferences, the structure of the local economy, and word-of-mouth communication to overall diffusion in individuals' investment choices in Section V. Section VI concludes.

\section{Data and Descriptive Statistics}

\section{A. Data}

We compile the data from several sources. The primary source is a large data set, obtained from a large discount broker, of individual investors' monthly positions and trades over a six-year period from 1991 to 1996. The data set covers all the investments that 78,000 households made through the discount broker, including common stocks, mutual funds, government and corporate bonds, foreign securities, and derivatives. Each household could have 
as few as one account and as many as 21 accounts (the median number of accounts is two). For a detailed description of the data set see Barber and Odean (2000).

In this paper we focus on the common stocks traded on the NYSE, AMEX, and Nasdaq exchanges. Common stock investments constitute roughly three-quarters of the total value of household investments through the brokerage house in the sample. We use the Center for Research in Security Prices (CRSP) database to obtain information on stock prices and returns and COMPUSTAT to obtain several firm characteristics, including company headquarters location (identified by its state and county codes). We use the headquarters location as opposed to the state of incorporation because firms often do not have the majority of their operations in their state of incorporation. ${ }^{2}$

The sample of households used in this study is a subset of the entire collection of households for which we could ascertain their zip code and thus determine their location. We obtained the latitude and longitude for each of the zip codes from the U.S. Census Bureau's Gazetteer Place and Zip Code Database. The corresponding company location comes from the COMPUSTAT Annual Research Files, which contain the information regarding the company headquarters' county code. Finally, we identify the latitude and longitude for each county from the U.S. Census Bureau's Gazetteer Place and Zip Code Database as well. We use the standard formula for computing the distance $\mathrm{d}(\mathrm{a}, \mathrm{b})$ in statutory miles between two points $\mathrm{a}$ and $\mathrm{b}$ as follows:

$\mathrm{d}(\mathrm{a}, \mathrm{b})=\arccos \left\{\cos \left(\mathrm{a}_{1}\right) \cos \left(\mathrm{a}_{2}\right) \cos \left(\mathrm{b}_{1}\right) \cos \left(\mathrm{b}_{2}\right)+\cos \left(\mathrm{a}_{1}\right) \sin \left(\mathrm{a}_{2}\right) \cos \left(\mathrm{b}_{1}\right) \sin \left(\mathrm{b}_{2}\right)+\sin \left(\mathrm{a}_{1}\right) \sin \left(\mathrm{b}_{1}\right)\right\} r$

where $a_{1}$ and $b_{1}\left(a_{2}\right.$ and $\left.b_{2}\right)$ are the latitudes (longitudes) of the two points (expressed in radians), respectively, and $r$ denotes the radius of the Earth (approximately 3,963 statutory miles).

We exclude the stocks we could not match with CRSP and COMPUSTAT; they were most likely listed on smaller exchanges. We also exclude stocks not headquartered in the continental U.S. The resulting "market"- the universe of stocks we could obtain the necessary characteristics and information about - is representative of the overall market. For example, at

\footnotetext{
${ }^{2}$ While we are aware that this is a somewhat imprecise measure, to our knowledge the data that detail the geographic distribution of employees for each company during the sample period are not available. Moreover, most value-relevant, strategically important information is likely concentrated at the company headquarters.
} 
the end of 1991 the "market" consists of 5,478 stocks that cover $89 \%$ of the overall market capitalization at the time.

In most of our empirical analyses, we relate the industry composition of a household's purchases during a quarter to the industry composition of all the purchases of the household's neighbors (households located within 50 miles) made during the quarter, plus appropriate controls. We choose this distance because there is evidence that 50 miles captures most of one's social interactions, including those that are employment-based. ${ }^{3}$

The sample size necessitates two adjustments. First, instead of fitting regressions based on individual stocks we aggregate all the buys in each quarter by assigning firms to one of the following 14 industry groups based on their SIC code: mining, oil and gas, construction, food, basic materials, medical/biotechnology, manufacturing, transportation, telecommunications, utilities, retail/wholesale trade, finance, technology, and services. Moreover, although 35,673 households purchased common stocks at some point during the sample period, in each quarter we consider only the households that made some purchases during the quarter. In sum, there are 23 complete quarters in the sample period (1991:1 to 1996:3), 14 industries, and 7,000 to 9,000 households that made purchases in a quarter. This leads to a total of 2,678,004 observations, where each observation has several control variables, as well as 322 industry-quarter dummy variables (14 industries x 23 quarters).

\section{B. Summary Statistics}

Table I summarizes quarterly household stock purchases at the industry level. Summary statistics are reported for the entire sample period (bottom row of the table) as well as annually. The first column presents the number of household, quarter, industry $(h, t, i)$ combinations in a given year for which household $h$ made at least one purchase in quarter $t$ in industry $i$. The second column tallies the number of distinct households appearing in the sample in a given year. The third column lists average dollar values of households' quarterly purchases, where median values are reported in parentheses directly underneath the mean values. The last two columns break down the purchases according to their distances from the household (i.e., whether the firm headquarters is located within 50 miles of the household) and their S\&P 500 status. There are a

\footnotetext{
${ }^{3}$ For example, according to the 1990 Census, $88 \%$ of the population lives within 25 miles of work (98\% live within 50 miles). Moreover, if two co-workers each live only 25 miles from work, they may live as many as 50 miles apart.
} 
total of 191,286 "purchases"-household-quarter-industry $(h, t, i)$ combinations for which there was a purchase by household $h$ in quarter $t$ in industry $i$ - with 16,000-20,000 households making purchases each year, for a total of 35,673 distinct households throughout the sample period. The distribution of the dollar values of quarterly purchases is skewed; while the mean quarterly purchase was around $\$ 29,000$, the median value was substantially smaller, around $\$ 8,000$. The fourth column shows individual investors' disproportionate preference for local stocks (17.1\% of all purchases), a phenomenon studied in Ivković and Weisbenner (2004) and Zhu (2002).

\section{Information Diffusion Effects: Basic Results}

\section{A. Basic Regression Specification}

At the outset, we classify individual stock purchases made by household $h$ in quarter $t$ into industries $i=1,2, \ldots, 14$ and compute the dollar-weighted share of a household's buys in each industry $\left(f_{h, t, i}\right){ }^{4}$ In various analyses, the aggregation into 14 industries is done across all stock purchases, local purchases only, and non-local purchases only. Moreover, for each household $h$ and each quarter $t$ we also compute $F_{-h, t, i}^{50}, i=1,2, \ldots, 14$, that is, the proportion of buys made by all neighboring households within 50 miles from household $h$ (excluding household $h$ ) in each of the 14 industries. For presentational convenience, throughout the paper the household industry shares $f_{h, t, i}$ are expressed in percentage points (that is, they are multiplied by 100), whereas neighboring household industry shares are not. Finally, we employ industryquarter effects to allow for market-wide variation in demand across industries and time by defining 322 dummy variables $D_{t, i}, t=1, \ldots, 23$ (from quarter 1991:1 to 1996:3), and $i=1,2, \ldots$ , 14. These controls ensure that our results are not driven by, for example, technology stocks beating analysts' expectations, which belong to the common information set that may affect buying patterns of all investors, but rather reflect the differences in households' propensity to purchase technology stocks across different communities. In sum, the basic regression is:

$$
f_{h, t, i}=\beta F_{-h, t, i}^{50}+\sum_{t=1}^{23} \sum_{i=1}^{14} \gamma_{t, i} D_{t, i}+\text { other covariates }+\varepsilon_{h, t, i}
$$

\footnotetext{
${ }^{4}$ Note that, by construction, for every $h$ and every $t, \Sigma_{i=1, \ldots, 14} f_{h, t, i}=100$.
} 
For the basic specification without other controls, the null hypothesis is that information diffusion effects ("neighborhood effects") do not exist, that is, that the coefficient $\beta$ is zero. A positive $\beta$ would be suggestive of the presence of the information diffusion effect.

We next address the correlation structure of the error term: observations are independent neither within each household-quarter combination (industry shares necessarily need to add up to one) nor across time (households' preferences are unlikely to change at quarterly frequency). It follows that the OLS regression estimation, although consistent, would produce biased standard errors. Thus, we report the standard errors and resulting tests of statistical significance that stem from employing a robust estimator that clusters observations at the household level for all regressions.

There are several reasons why individuals' investment choices might be related to those made by their neighbors. At the outset, we note that individual investors might be reacting to the same publicly available information to which their neighbors are reacting. Such tendencies may cause correlated trading. Indeed, Barber, Odean, and Zhu (2003) document that trading patterns are correlated across individual investors and Barber and Odean (2002) find that individual investors are inclined to buy stocks that attract attention. These correlated trading patterns are not necessarily surprising in light of exposure to (the same) publicly available information, as well as to the pronounced presence of the disposition effect (Odean, 1998), tax-motivated trading, and/or other behavioral phenomena that might prevail among individual investors, yet need not be driven by information diffusion effects. Our basic set of 322 industry-quarter dummy variables seeks to control for these and other trading factors that do not vary across communities (e.g., when a stock price reaches an all-time high, it does so for all investors) and thereby to allow our specifications to pick up information diffusion effects.

Results of running the basic regression, without any controls other than the 322 industryquarter dummies, are summarized in Figure 1. It presents both the results for the pooled data across all 23 quarters and quarter-by-quarter results (in which case each regression only has 14 dummy variables for the industry effects). The estimated coefficient $\beta$ is highly statistically significant in all twenty-four regressions. Overall, information diffusion effects appear to be strong. For pooled observations, the estimate of $20.7 \%$ suggests that a $10 \%$ change in the neighbors' allocation of purchases in an industry is associated with a nearly $2.1 \%$ change in the household's own allocation of purchases in the industry. Quarterly regressions suggest that, 
although point estimates vary somewhat from quarter to quarter (from 13.6 to 28.3), information diffusion effects are strong throughout the sample period.

\section{B. Information Diffusion Effects for Local and Non-Local Purchases}

As discussed in the introduction, information diffusion that prevails among local and non-local stocks may be different. Similarity in preferences, the structure of the local industry, and word-of-mouth effects are likely stronger among local investments. This inquiry is also motivated by studies of local bias among both institutional investors (Coval and Moskowitz (1999)) and individual investors (Ivković and Weisbenner (2004) and Zhu (2002)). Those studies find that both groups of investors are biased toward holding disproportionately more local stocks in their portfolios. Moreover, Coval and Moskowitz (2001) and Ivković and Weisbenner (2004) present evidence that local investments outperformed non-local ones among mutual fund managers and individual investors, respectively.

We present the results of testing this hypothesis by fitting the regression from Equation (2) for various dependent variables in Table II. Panel A focuses on the entire universe of stocks, whereas Panels B and C presents results only for S\&P 500 and non-S\&P 500 stocks, respectively. Within each panel every row pertains to a different left hand side variable. The first row pertains to the industry share breakdown $f_{h, t, i}$ computed across all buys and the next two rows pertain to the industry composition breakdowns computed across local purchases 5 only and non-local purchases only, respectively.

The coefficient $\beta$ reported in Panel A for all buys is 20.7 , an estimate already presented in Figure 1. Separate consideration of local and non-local buys reported in the next two rows reveals that the local information diffusion effect is an order of magnitude larger than the nonlocal one (119.3 vs. 8.4). For example, if the neighborhood's allocation of local purchases to a particular industry increases by ten percentage points, a household tends to increase its own allocation of local purchases to the industry by a comparable amount. This result adds another dimension to the (already documented) high degrees of individual investors' locality, both in the U.S. (Ivković and Weisbenner (2004), Zhu (2002)) and abroad (Grinblatt and Keloharju (2001),

\footnotetext{
${ }^{5}$ In the regressions for local buys we discarded all the $h, t, i$ observations for which there were no firms in industry $i$ within 50 miles from household $h$ in quarter $t$ because the household simply could not invest into industry $i$ locally.
} 
Massa and Simonov (2003)). The results presented herein suggest the possibility that strong information diffusion effects could contribute to individual investors' local bias.

Panels B and C address the degree of informational asymmetry between well-known stocks of established companies and relatively obscure stocks. We use a simple proxymembership in the S\&P 500 index - to differentiate between the two. A comparison of Panels B and $\mathrm{C}$ with Panel A suggests that the overall pattern of information diffusion coefficients is preserved among both S\&P 500 and non-S\&P 500 stocks. The magnitudes of the coefficients in the two panels suggests that both local and non-local information diffusion may be somewhat more pronounced among S\&P 500 stocks (Panel B) than among non-S\&P 500 stocks.

An issue of potential concern for local information diffusion is the possibility that the effect may be driven by some form of inside trading: those who work for a company may be trading in their own company stock and may be selectively releasing pertinent information to their close friends and relatives. We regard this effect as somewhat distinct from the other aspects of information diffusion because the information the investors would receive is likely much more precise than the information available through word-of-mouth effects, exposure to local news, influence of company's presence through advertising efforts, company-sponsored events, or social interaction with company employees.

Unfortunately, the data set does not provide information about the investors' current and past employers. Consequently, it is impossible to identify whether (and to what extent) households hold their employers' stocks. Still, we can control for the own-company stock explanation by focusing on the plausible, but rather conservative assumption that, if a household's local purchase is motivated by inside information, it is likely to be the household's largest local trade in that quarter. Pursuant to that assumption, we compute for each household $h$ in quarter $t$ the industry composition of local purchases excluding the single largest stock purchase made by household $h$ in quarter $t$. In unreported analyses, we find that this specification yields estimates of the local information diffusion effect that are even somewhat larger than the estimates based on the full sample of local investments (152.5 versus 119.3) and conclude that we do not find evidence that trading in own-company stock drives the estimated information diffusion effects among local investments.

Another issue of potential concern is that the estimates of local information diffusion may be induced by the dominant presence of a company (or industry) in a household's neighborhood. 
Taking a drastic example, suppose there is only one company (or multiple companies all belonging to the same industry) local to the household. The opportunity set for local investments is therefore very focused and the inability to invest locally into any other industry may bias the results. To assess the impact of industry dominance in the local opportunity set we run regressions for local purchases while removing certain observations. In unreported results, we consider a subsample of purchases - household-quarter-industry $(h, t, i)$ combinations for which the weight of industry $i$ in the portfolio of firms local to household $h$ does not exceed the threshold of $50 \%$, that is, the observations not plagued by the domination of a single company (or industry) in the community. The regression coefficient remains essentially the same; it declines only very slightly, from 119.3 to 111.3 , which suggests that the "one-company town" issue does not drive local information diffusion.

\section{Dissipation of Information Diffusion Effects Across Time and Space and the Role of Location}

\section{A. Lags in Information Diffusion Effects}

The analyses to this point focused on the contemporaneous relations between households' purchases and purchases made by their neighbors (households within 50 miles from the household). However, individuals may be influenced by their neighbors' past stock trades as well. Accordingly, we reflect this possibility by considering specifications that allow for lags of up to four quarters. Unlike regressions reported to this point, in which market-wide demand for stocks in particular industries over time was absorbed by industry-quarter dummy variables, we now explicitly compute for each household $h$ and quarter $t$ the share of stock purchases across industries for all households except household $h$ in quarter $t, F_{-h, t, i}^{A l l}, i=1,2, \ldots, 14$, and run the following regression:

$$
f_{h, t, i}=\beta_{0} F_{-h, t, i}^{50}+\beta_{0}^{A l l} F_{-h, t, i}^{A l l}+\sum_{j=1}^{4} \beta_{-j} F_{-h, t-j, i}^{50}+\sum_{j=1}^{4} \beta_{-j}^{A l l} F_{-h, t-j, i}^{A l l}+\varepsilon_{h, t, i}
$$

Table III presents results of running four specifications with varying explanatory variables: contemporaneous only in the first column, lagged by one quarter only in the second 
column, both contemporaneous and lagged by one quarter in the third column, and both contemporaneous and lagged by up to four quarters in the fourth column. Column (1) replicates the basic result from Table II with a slightly different way of controlling for market-wide demand for stocks at the industry level; the estimate of the contemporaneous information diffusion coefficient (22.1) is very close to the baseline estimate from Table II (20.7). Column (2) allows only for independent variables lagged by one quarter; the point estimates are very similar to those reported in column (1), suggesting that even a very conservative specification that captures information diffusion by relating current household purchases to their neighbors' past purchases at the industry level uncovers a strong effect. Allowing both contemporaneous effects and effects with a one-quarter lag, as suggested by column (3), shows that both contemporaneous and lagged purchasing decisions made by a household's neighborhood are related to the household's current purchasing decisions. While the coefficient estimates are somewhat attenuated relative to those reported in columns (1) and (2), both are still fairly large (16.5 and 14.0, respectively). On the other hand, coefficients related to purchases made by all households differ considerably: the current quarter's coefficient is four times larger than the lagged quarter's (42.9 vs. 9.4). Finally, column (4) suggests that information diffusion effects extend beyond a single lagged quarter: regression coefficients pertaining to lagged purchases made by the households' neighborhoods persist for all four lagged quarters and amount to a total of 41.2. Thus, individual investors appear not to be influenced only by their neighbors' most recent purchases; rather, they are influenced by the neighbors' purchases made across an extended period of time - up to one year (four quarters).

By contrast, in this specification only contemporaneous purchases made by all households have a consistently strong effect (coefficient estimate of 40.4), reflecting perhaps the impact of current national news. Lagged coefficients vary in sign and are much smaller in magnitude and, moreover, an $F$-test rejects their joint significance at the one-percent level. It appears that, although lagged market-wide news may have affected trading when it first became available, it no longer impacts current trading.

\section{B. Dissipation of Information Diffusion Effects with Distance from the Household}

One would expect information diffusion effects to dissipate as the distance from the household increases. For example, households located more than 100 miles away from a 
household should have weaker effect on the household's portfolio decision than households located within 50 miles. To test this, we define regions surrounding the household at increasingly larger distances as follows: 0-50 miles, 50-70.7 miles, 70.7-86.6 miles, 86.6-100 miles, ..., 141.4-150 miles. The prevailing criterion is that these regions should cover a geographic area of the same size $\left(50^{2} \pi=7,854\right.$ square miles). Accordingly, we run a regression similar to Equation (2), except, instead of having one information diffusion regressor $F_{-h, t, i}^{50}$, we now have nine $\left(F_{-h, t, i}^{50}, F_{h, t, i}^{50-71}, F_{h, t, i}^{71-87}, F_{h, t, i}^{87-100}, F_{h, t, i}^{100-112}, F_{h, t, i}^{112-122}, F_{h, t, i}^{122-132}, F_{h, t, i}^{132-141}\right.$, and $F_{h, t, i}^{141-150}$ ). The results of this regression are presented graphically in Figure 2. Across all three panels, that is, for all buys, local buys, and non-local buys, the pattern is the same: there is a rapid and steady exponential decline of the information diffusion coefficients with distance from the household.

\section{Information Diffusion Effects and Local Population}

In this section we stratify households according to the size of the population that resides within 50 miles from the household. We define four categories: 0-1 million residents, 1-2.5 million residents, 2.5-5 million residents, and more than 5 million residents (the latter includes households in and around New York City, Los Angeles, and Chicago). Not surprisingly, the size of the local population and the diversity of local companies are positively related. Specifically, the Herfindahl index of the industry composition of firms local to the average household decreases from around 0.5 to around 0.2 as the population increases from $0-1$ million local residents to more than 5 million local residents. ${ }^{6}$ Yet, although the average number (and dollar amount) of quarterly purchases of local individual stocks increases from $1.4(\$ 13,000)$ to 1.7 $(\$ 22,400)$, the Herfindahl index of households' local purchases across industries remains virtually unchanged - it drops only very slightly — as the size of the local population increases (from 0.99 to 0.95 for populations of $0-1$ million and more than 5 million local residents, respectively). Thus, although residents in larger metropolitan areas have substantially more diverse investment opportunities and tend to invest more into local stocks, they tend to remain very focused in their industry allocation. This tendency is consistent with the notion that

\footnotetext{
${ }^{6}$ Firms are divided into 14 industry groups. Thus, a community with equal representation across all industries would have a local firm Herfindahl index of 0.07 .
} 
residents in more populous geographic areas might be exposed to information diffusion effects to a higher degree than residents in less highly populated areas are. To confirm this intuition we run a simple modification of the basic regression from Equation (2) on subsamples selected by the type of purchase (all buys, local buys, and non-local buys) wherein information diffusion effects are interacted with dummies representing local population size (0-1 million, 1-2.5 million, 2.5-5 million, more than 5 million). The coefficient estimate presented in the table for a particular population group represents the total information diffusion effect for that group (i.e., the sum of the diffusion effect for the $0-1$ million group and the interaction term for that particular population group).

Across all three panels of Table IV the results suggest that the information diffusion effects increase with population size. Stronger information diffusion effects in larger metropolitan areas may stem from the intensified flow of investment-relevant information through increased availability of information sources (e.g., business-oriented magazines and newspapers) and advertising efforts, both of which are subject to economies of scale and are typically more substantial in larger metropolitan areas.

\section{Information Diffusion Effects in Large U.S. Cities}

The preceding section shows that the information diffusion effects are stronger in larger metropolitan areas. Still, it is entirely possible that relatively few U.S. cities could be driving this effect. Generally, there could be considerable heterogeneity among information diffusion effects in individual large cities. In the following analysis, we identify 25 large U.S. cities and collect the rest of investors into the $26^{\text {th }}$ "city" $R$ ("Rest of Investors"). To explore information diffusion effects among households in 25 major U.S. cities we run a regression wherein we relate the share of purchases across industries for each household with those of the residents of the same city and those of the residents of all other major cities and the rest of the investors (i.e., those that do not reside in one of the 25 cities):

$$
f_{h, t, i}=\sum_{c=1}^{25} \alpha_{c} F_{c-h, t, i} I(h \in c)+\sum_{c=1}^{26} \beta_{c} F_{c, t, i} I(h \notin c)+\varepsilon_{h, t, i}
$$


where the indicator function expression $I(h \in c)$ means that household $h$ resides in city $c$. Thus, for a given city $c, c=1, \ldots, 25,\left(\alpha_{c}-\beta_{c}\right)$ represents the effect of a change in industry allocation in city $c$ upon households in that city relative to households that live elsewhere. This approach follows very closely the key specification from Hong, Kubik, and Stein (2003), with one exception: in light of the nature of our data (there are many more individual investors in the present data set than there are money managers in the sample used by Hong, Kubik, and Stein (2003)), rather than considering individual stocks we focus on industry-level stock purchases. This regression framework allows for a close comparison of information diffusion effects of individual investors to those prevailing among mutual fund managers.

Table $\mathrm{V}$ present results of fitting the regression from Equation (4). The first two columns focus on all buys. While there is some variation in the information diffusion coefficients $\alpha_{c}$ (related to a household's own city), they are all fairly large and are each much larger than the corresponding information diffusion coefficients $\beta_{c}$ (related to other cities). For example, the information diffusion coefficients of 40.4 and 8.4 for Los Angeles, respectively, mean that a 10 percentage point increase in the portfolio share of Los Angeles' households allocated to, for example, technology, will boost the technology share of a Los Angeles resident by $4 \%$, but will only boost the technology share of a household's purchases in another city by $0.8 \%$. In fact, the weighted-average difference between the two information diffusion coefficients, that is, $\left(\alpha_{c}-\right.$ $\beta_{c}$ ), across the twenty-five cities is $35 \%$. That is, a ten percentage-point change in industry allocation in a particular city will tilt the purchases made in that industry by 3.5 percentage points more for a household residing in that city than for a household residing elsewhere. The next two pairs of columns replicate the same analysis for local purchases and non-local purchases. Except for a difference in the magnitude of the effect - the information diffusion from a household's city is much larger for local purchases than for non-local purchases and the difference between the own-city effect and the other-city effect is much larger for local purchases than for non-local purchases (97.9 and 10.9, respectively) - the same conclusion holds. Overall, we present evidence of a strong dominance of the own-city effect over the othercity effect and our results are consistent with, and somewhat more pronounced than, those pertaining to mutual fund managers (Hong, Kubik, and Stein (2003)). For example, while our basic specification yields the estimate of 35\%, the comparable specification in Hong, Kubik, and Stein (Table 2, 2003) yields a coefficient of $22 \%$. 


\section{Heterogeneity of Information Diffusion Effects and Their Relation to Future Industry-Level Returns}

\section{A. Heterogeneity of Information Diffusion Effects Across Industries}

In the following analyses, carried out separately for each industry on the subsamples of all buys, local buys and non-local, we fit two specifications. The first specification employed for each industry is very similar to the baseline specification, outlined in Equation (2), with only 23 quarter-dummies and without any additional controls. In the second specification we include 15 controls that capture household investment style ${ }^{7}$ to answer the question whether, after controlling for a household's preference to invest, for example, in high-momentum, small, low book-to-market firms, the neighborhood's allocation of purchases across industries still influences the household's own allocation. Put differently, a household's propensity to buy technology stocks could be driven by its neighborhood's propensity to buy technology stocks and/or by the household's preference for firms that exhibit characteristics that are correlated with characteristics of technology stocks; this analysis seeks to disentangle these two potentially conflicting effects.

The results are presented in Table VI. The first column shows the results of fitting the first, baseline specification. It suggests that there are differences among the information diffusion estimates obtained industry-by-industry, with the largest, statistically significant estimates for technology stocks, followed by retail trade and services. With the exception of all buys of construction stocks, coefficient estimates for both all buys and local buys are positive and statistically significant. As for non-local buys, the information diffusion coefficient $\beta$ in the baseline specification is statistically significant for 10 out of the 14 industries. Moreover, the information diffusion effects appear to be much stronger for local buys than for non-local buys, for some industries even in excess of an order of magnitude. Although the 15 style dummies

\footnotetext{
${ }^{7}$ Each of the household's individual stock purchases is characterized by the stock's size, book-to-market, and past year's return. The three characteristics are sorted in each quarterly cross-section and divided into quintiles. Each stock purchase is associated with 15 auxiliary variables. The first five auxiliary variables are set to one if the stock belongs to the respective size quintile and to zero otherwise; the next five are defined analogously for stock's bookto-market ratio; the last five auxiliary variables are defined analogously for stock's recent performance over the 11 months preceding the month of purchase. The fifteen controls are computed as weighted sums of the respective fifteen auxiliary variables across all the purchases made by the household in the quarter and thus represent the share of quarterly purchases in each size, book-to-market, and momentum quintile. This approach is also employed by Hong, Kubik, and Stein (2003).
} 
have significant explanatory power of their own, their inclusion in the specification seems to have had virtually no effect on the information diffusion coefficient; most of the regression coefficients are very similar to those reported in the respective columns for the baseline specification.

\section{B. Time-Variability of Industry-Level Information Diffusion Effects}

The industry-by-industry regressions reported in Table VI suggest some degree of heterogeneity among industries with respect to the intensity of information diffusion effects. Table VII provides summary statistics obtained by running industry-by-industry regressions separately for each of the 23 quarters, for a total of 322 estimates. Results for all buys, local buys, and non-local buys suggest that there is nontrivial time variation in the magnitude of the information diffusion effect point estimates. Technology stocks feature the largest average of point estimates for all buys and non-local buys and the second largest for local buys. In all three cases, their interquartile range is fairly tight. Several other industries, such as medical/biotechnology, retail trade, and services also had fairly large averages, whereas some other industries are interesting because they featured low averages for all buys and non-local buys, yet had high averages for local buys (e.g., oil and gas, construction, and food). The last row of Table VII reports the summary statistics taken across all 322 estimates of the information diffusion coefficient $\beta$. Roughly speaking, it suggests that the effect for all buys is an order of magnitude smaller than it is for local buys (average coefficient estimates are 8.9 and 97.2, respectively) and is more than twice as large as it is for non-local buys (average coefficient for non-local buys is 3.7 ).

\section{Do Diffusion Effects Predict Future Returns? The Portfolio Formation Approach}

In light of strong information diffusion effects, that is, evidence of correlated trading behavior across industry-level purchases, we next explore whether our estimates of information diffusion can predict industry-level returns. Intuitively, our inquiry may be interpreted as a simple question as to whether industry-level diffusion effects among individual investors can create sufficiently concentrated trades and thus "momentum" to impact future industry-level returns? 
In this section we implement a simple portfolio formation strategy wherein at the end of each quarter $t$ the fourteen industries are sorted according to their information diffusion estimates $I \hat{D}_{t, i}$. The industries are then classified into three categories: top five, bottom five, and middle four. This classification serves as the basis for forming a zero-cost portfolio. The returns to the long (short) size of the portfolio are equally-weighted returns to the top (bottom) five industries. These positions can be held during the next quarter only, in which case the portfolio is completely redefined each quarter, or over a longer horizon of one year. In the latter case, the overall portfolio consists of four sub-portfolios, all of which are equally weighted, and only onefourth of the portfolio is modified each quarter. Finally, in light of highest estimates of information diffusion effects among technology stocks, we introduce a robustness check wherein we remove technology stocks from the long side of the portfolio in all quarters in which it would be classified among the top five industries (which occurs in most quarters). This entire procedure is carried out for estimates of information diffusion among all buys, local buys, and non-local buys. We control for risk using the four-factor model (i.e., the three Fama-French (1993) factors and the fourth momentum factor) proposed by Carhart (1997).

The results of analyzing the performance of these zero-cost portfolios are presented in Table VIII. The table presents the loadings on the four factors and the risk-adjusted performance (Alpha) for each of the nine portfolios. Moreover, the bottom row of the table presents raw returns on each of the zero-cost portfolios. The bottom two rows suggest that the risk-adjusted returns are positive for all portfolios, although Alpha is consistently statistically significant only across the portfolio strategies based on non-local diffusion. Those analyses suggest that chasing information diffusion effects concerning non-local industry-level purchases in the sample would have resulted in abnormal portfolio performance of around seven percentage points per year (under the assumption of quarterly rebalancing), both including and excluding the technology industry. As suggested by the high $p$-value of the four-factor model regressions with the 3-month holding period, there is no systematic difference in the two portfolios formed on non-local diffusion (i.e., no difference in loadings on the four factors). The effect of non-local information diffusion appears to weaken fairly quickly, as the estimate related to the 12-month holding period (involving up to four equally-weighted overlapping sub-portfolios), aside from being only marginally statistically significant, is reduced by one-half in comparison with the quarterly rebalancing strategy. 


\section{Alternative Perspective: The Industry-Level Panel Data Approach}

As a robustness check to the strong returns following high non-local information diffusion, we relate industry-level returns prevailing over the next period not only to current information diffusion effects, but also to industries' current performance, individual investors' demand for stocks at the industry level, as well industry and quarter effects. The regression at the quarterly horizon is specified as follows:

$$
R_{q+1, i}=\beta_{I D}^{N L} I \hat{D}_{t, i}^{N L}+\beta_{R} R_{q, i}+\beta_{B S I} B S I_{t, i}+\sum_{t=1}^{23} \gamma_{t} D_{t}+\sum_{i=1}^{14} \delta_{i} D_{i}+\varepsilon_{t, i}
$$

where the first regressor is the quarterly industry-level non-local information diffusion estimate, the second regressor represents lagged industry-level returns, the third regressor captures industry-level demand, and the remaining regressors are controls for industry and quarter effects. The industry-level demand is computed as the difference between buys and sells of stock in the given industry divided by their sum: $B S I_{t, i}=\left(\$\right.$ Buys $\left._{t, i}-\$ \operatorname{Sells}_{t, i}\right) /\left(\$\right.$ Buys $\left._{t, i}+\$ \operatorname{Sells}_{t, i}\right)$. This approach follows Lakonishok, Shleifer, and Vishny (1992). The annual regression differs only in regard to the horizon of future industry-level returns (i.e., the left-hand-side variable) - those returns stretch across the next four quarters.

Panel A of Table IX presents results for the regression involving quarterly industry-level returns. Each of the three specifications introduces increasingly more controls, culminating in column (3) that features the full set of control variables from Equation (5). Information diffusion effects of non-local purchases are consistently (though marginally) statistically significant across all of the specifications. The impact of non-local diffusion is economically significant: the point estimate of 0.08 and the interquartile range of quarter-industry non-local information diffusion effect from the last row of Table VII (-1.4 to 7.3) suggest that a change in the information diffusion effect for an industry equal to the interquartile range (that is, around 8.7) is associated with a 70 basis points increase in next quarter's returns for the industry (which translates into approximately $2.8 \%$ per year). Similarly, results from column (3) in Panel B suggest a 2.0\% increase in annual industry level returns $(8.7 * 0.23)$, although the evidence is only marginally statistically significant. In sum, controlling for the pattern of buying/selling activity, non-local information diffusion effects have predictive power for future industry-level returns. 


\section{E. Toward Understanding the Predictive Power of Non-Local Industry-Level Information Diffusion Effects}

The analyses presented in Tables VIII and IX offer compelling evidence that industrylevel non-local information diffusion can predict industry-level returns, where the magnitude of the effect is estimated to lie in the range from two to seven percentage points per year. In this section we offer an insight into a plausible mechanism that might generate such a pattern.

Empirical evidence is mounting that individual investors are able to exploit informational asymmetries embedded in stocks local to them (Ivković and Weisbenner (2004)). ${ }^{8}$ Consistent with such evidence, we show that individual investors' purchases of local stocks outperform their purchases of non-local stocks (Panel A in Table X). This finding suggests that a certain fraction of "good" value-relevant information is generated locally.

Second, local information diffusion effects are statistically significantly related to both contemporaneous and future (by up to three quarters) non-local diffusion effects, but not to lagged non-local diffusion effects. Specifically, the correlation between local "word-of-mouth" effects and contemporaneous non-local "word-of-mouth" effects is 0.11 and is statistically significant; the correlation between local effects and future non-local effects remains strong and statistically significant for the next three quarters (the correlations are $0.17,0.12$, and 0.10 , respectively). Put differently, an intense flow of investment information started locally continues non-locally for quite a while and non-locals may be enticed to buy those stocks about which they (eventually) receive some information.

Panel B of Table X provides evidence that, consistent with the disposition effect documented in Odean (1998), investors tend to sell local stocks too soon-local purchases continue to outperform non-local purchases following their sale (the differential in terms of both raw returns and risk-adjusted returns is positive, yet it lacks statistically significance for riskadjusted returns). Non-locals, on the other hand, being net buyers of stocks previously (and perhaps concurrently) sold by locals, may still reap some benefits from the original "good" value-relevant information generated locally.

\footnotetext{
${ }^{8}$ Similarly, Coval and Moskowitz (2001) show that professional managers' local investments outperform their nonlocal investments.
} 


\section{Disentangling Information Diffusion Effects}

The results presented in Section II suggest that the stock purchases made by households are strongly related to those made by their neighbors, consistent with word-of-mouth effects playing a strong role in household investment decisions. However, such a correlation in trading activity could also reflect an underlying similarity in preferences and/or the industry-composition of local firms. In regard to U.S. investors, studies have found correlated trading patterns both for institutional investors (Hong, Kubik, and Stein (2003)) and individual investors (Barber, Odean, and Zhu (2003)), but have not explored why such correlated trading patterns obtain. To our knowledge, the only study that addresses this issue focuses on individual investors in the People's Republic of China (Feng and Seasholes (2004)) and finds that correlated trading is related to the flow of local information, but is not related to word-of-mouth effects that could result from executing trades in the same branch office.

Unlike Feng and Seasholes (2004), we do not have what is essentially a natural experiment - the investors in our sample can place trades by phone, over the Internet, or in person, rather than being required to place trades in the specific brokerage house in which they opened an account. Instead, we devise an alternative strategy to disentangle the sources of the observed correlation between a household's stock purchases and those of its neighbors. In particular, we consider three key contributions to the overall information diffusion effect, namely, word-of-mouth communication, correlated preferences (which may incorporate common reaction to news events), and the structure of the local economy.

We use the composition of the neighborhoods' aggregate portfolio to reveal the neighborhoods' preferences and the accumulation of their reactions to past news. Analogously, we use the composition of a household's own portfolio position to reveal its own preferences and accumulated reactions to past news. We further use the degree of conformity of the household portfolio composition to the portfolio composition of the neighborhood to identify households with preferences and reactions similar to their neighbors', as well as those whose preferences and reactions are very different from their neighbors'.

Upon controlling for the composition of households' neighborhood portfolios and households' own portfolio compositions, as well as the structure of the local economy, we view 
the correlation between the household's stock purchases and those of its neighbors that survives such rigid controls as a conservative lower bound on the magnitude of the word-of-mouth effect. Strikingly, our estimates of the contribution of word-of-mouth communication are very similar across households that conformed to their neighbors very closely and those that held very disparate portfolios. This finding is reassuring because it suggests that the strategy we employed to control for the effect of common preferences and the cumulative common reactions to news did not lead to materially different estimates of the word-of-mouth effect across the two sets of households.

It is important to differentiate among these competing sources of the overall information diffusion effect because they likely have different levels of influence on the market. For example, word-of-mouth effects may create a more dynamic exchange of information that may lead to a ripple effect of further information dissemination, which in turn may have an impact on stock prices.

\section{A. The Role of Correlated Preferences}

A potential source of correlated purchases among households in a geographic area is that these households may have similar preferences. Individual investors might be influenced by their neighbors' investment choices because they wish to conform and keep pace with their neighbors' wealth and investment habits (Bernheim (1994), Campbell and Cochrane (1999), and Shore and White (2003)). Moreover, to the extent that individuals choose their place of residence according to their preferences, and those tend to be correlated among the residents of the same geographic area, it is possible that similar tastes might govern investment decisions even without explicit communication with their neighbors. Finally, it is plausible that individual investors' own

preferences are correlated over time; individuals might have an inclination to conform to some of their previous investment choices (to the extent of favoring stocks from the same industry as they previously did).

To explore the effect of correlated preferences, we define two variables for each $(h, t)$ observation. First, we define the industry composition of stock positions of neighboring households (excluding household $h$ itself) at the end of quarter $t-1$. Second, we define the industry composition of stock positions of the household itself at the end of quarter $t-1$. The inclusion of these two position-related variables in the specification explicitly accounts for any 
underlying correlation in trading activity attributable to a similarity in preferences within a community that manifests itself in a similarity of stock purchases within the community or a similarity in an individual's own stock preferences over time. This approach requires merging purchases in quarter $t$ with positions at the end of quarter $t-1$. While there is substantial overlap between household identifiers for trades and positions in the database, the matching is imperfect and it allowed us to retain around two-thirds of the original observations used in previous analyses.

\section{B. The Structure of the Local Economy}

Companies routinely seek to generate a certain presence in the local community. One immediate effect of such endeavors is investors' enhanced familiarity with local companies, generated through social interaction with employees and company efforts such as local advertising and sponsoring local events. Investors' propensity to invest in the companies (industries) they are familiar with, and perhaps even informed about, undoubtedly constitutes one important facet of information diffusion. Moreover, the local presence of a company may enhance the probability of circulation of very precise, inside information, an issue we addressed to a certain extent in Section II.

To capture the impact of the structure of the local economy, we define variables that capture the distribution of the local economy and local labor force across industries. Specifically, for each $(h, t, i)$ observation we define two variables: the fraction of market value of companies local to household $h$ in quarter $t$ in industry $i$ and the fraction of the labor force local to household $h$ in quarter $t$ employed in industry $i{ }^{9}$

Including these two variables should pick up both the effects that stem from familiarity with local companies and the potential direct company-stock effect. For example, if there are many employees working for construction companies in the area, a household's propensity to invest in construction firms could stem from word-of-mouth effects - social interaction between these employees and other households - and/or these employees investing in their own company stock (company-stock effects).

\footnotetext{
${ }^{9}$ We obtain the number of employees from COMPUSTAT. For the purpose of this analysis we assume that all the company's employees are employed in the same county in which the company headquarters are located. We are aware that this is a somewhat imprecise measure, but, to our knowledge, more precise panel data regarding the geographic distribution of the employees for each company are not available.
} 
Figure 3 presents average compositions of quarterly buys, firms local to the household, and corporate workers local to the household over the entire sample period. The figure shows that the purchases made by the individual investors in the sample were tilted toward technology and medical/biotechnology industries: around one-third of all purchases were in technology stocks and a further one-sixth in medical/biotechnology stocks. Moreover, the figure suggests that there may be a relatively high correlation between the composition of individuals' purchases and the local economy, that is, market values and corporate workers in the individuals' neighborhoods (within 50 miles).

Industry compositions of households' total buys are more correlated with their neighbors' buys (0.34) than they are with either market values of local firms $(0.15)$ or employees of local firms (0.16). There is a striking contrast in the effect that local firms have on households' local buys versus households' non-local buys. Specifically, the correlation between the industry composition of local firm value (employees) and the industry composition of local buys is 0.41 (0.40), while the comparable correlation for non-local buys is $0.10(0.11)$. The higher correlations related to local buys could partially reflect company-stock issues, namely, the propensity to invest in a firm for which household members work (or have worked). On the other hand, the correlations related to non-local buys likely do not reflect this concern; instead, they likely reflect the fact that households' familiarity with local investment opportunities influences households' remote investments as well.

\section{The Results}

The results of relating the industry composition of a household's investments to the neighborhood's preferences, own preferences, and the structure of the local economy are presented in Table XI. Panel A has three sections, containing estimates for all buys, local buys, and non-local buys, respectively. Within each section, we first show the baseline result, which corresponds very closely with the corresponding baseline result in Table II, Panel A. ${ }^{10}$ The following row in each section shows the results with the two additional independent variables that seek to capture preferences for industry allocation. Both variables are statistically significant, which suggests that households' purchases across industries are related to the

\footnotetext{
${ }^{10}$ The small discrepancies between the point estimates (e.g., 19.9 in Table XI vs. 20.7 in Table II for all buys) can be attributed to the differing numbers of observations.
} 
common preferences that prevail in their neighborhoods, as well as their own revealed preferences (as described by their current common-stock positions). For example, the point estimates suggest that households that enter the quarter with a stock portfolio fully concentrated in a particular industry allocate 31-48 percentage points more of their quarterly purchases to that same industry. The point estimate of $\beta$, interpreted as the information diffusion effect unrelated to such preferences or the word-of-mouth component, is equal to one-half of the magnitude of the estimated effect of the overall information diffusion (Table II, Panel A) for all buys and nonlocal buys, and to one-third for local buys.

The third row in each section of Panel A includes the variables that capture the structure of the local economy. Both local-economy variables are positively related to the allocation of household purchases across industries and are statistically significant, although they tend to attenuate the estimate of $\beta$ to a much lesser degree than do the two variables related to preferences. Although the effect of the structure of the local economy is present for all the subsamples, the impact is by far the strongest for local buys. Specifically, a 10 percentage point change in the presence of a certain industry (as measured by firm values) is associated with a 4.7 percentage point change in the allocation of a local household's local purchases across industries. The impact of the industry-level structure of the local labor force is also noticeable (1.4 percentage point change), though it is not as strong.

The fourth row in each section features the results of relating the industry composition of a household's investments to both preferences (the neighborhood's and own) and the structure of the local economy. Estimates of the effects of all the four variables are positive and statistically significant. Most importantly, the point estimate of $\beta$, interpreted as the information diffusion effect unrelated to either preferences or the structure of the local economy, approximately equals one-half of the magnitude of the estimated effect of the overall information diffusion for all buys and non-local buys, and one-third for local buys. Figure 4 illustrates the estimates of the overall information diffusion effect for all buys (as presented in Figure 1), plotted using gray bars, and the word-of-mouth component for all buys, plotted using black bars. The estimates for the full sample period are plotted using full bars, whereas quarterly estimates are plotted using dotted bars. For the full sample, word-of-mouth communication accounts for nearly one-half of the overall information diffusion effect. This is a very robust estimate because inspection of period- 
by-period estimates suggests that word-of-mouth communication accounts for $40 \%$ to $50 \%$ of the overall information diffusion effect in most quarters.

The final analysis reported in Panel A of Table XI seeks to capture differences among households along unobservable characteristics by running the baseline regression from Equation (2) with the inclusion of household-level fixed effects. This is a very rigorous test, as it presents a higher standard than the baseline specification: it relates the change in a household's allocation of purchases to an industry from its time-series average allocation of purchases to the industry with the change in its neighborhood's allocation of purchases to the industry from the neighborhood's time series average allocation of purchases to the industry. For example, an investor who likes technology stocks may happen to live in an area where others independently also happen to invest in technology stocks. Such a non-causal correlation would lead toward the detection of diffusion effects in a cross-sectional regression even if investors acted independently. By contrast, to identify diffusion effects in a panel regression requires that, in response to a change in community technology stock investment, the household should change its allocation to technology stocks in the same direction. Results in the last row of each section in Panel A are compelling; they suggest that information diffusion effects remain strong in the household fixed-effects framework, especially for local buys (3.6 for all buys; 17.7 for the subsample of local buys; 2.4 for the subsample of non-local buys), though the magnitudes are substantially reduced compared to the cross-sectional analyses.

The extent to which households' portfolios conform to those of their neighbors can serve as a proxy for identifying households whose purchasing decisions are driven to varying degrees by the desire to adhere (inadvertently or not) to the preferences and common news prevailing in their neighborhood. For example, if the household shared the investment preferences with its neighborhood and responded to news similarly to its neighborhood, over time its portfolio composition would be very similar to that of its community.

We sort households into two types according to the extent to which their household portfolio allocations at the industry level conform to those of their neighbors; the metric we use is the average absolute deviation in industry portfolio shares between a household and its neighborhood. Results in Panels B and C of Table XI suggest that, while initially there are substantial differences in information diffusion effects (i.e., coefficients associated with the composition of buys of neighboring households) across the two groups, once the variables that 
capture preferences and the structure of the local economy are included, the estimated coefficient $\beta$ (i.e., the relation between a household's purchases and its neighbors' purchases) becomes fairly similar across the two types of investors. Specifically, the $\beta$ for local (non-local) buys across the two groups of investors are 46.2 and 29.4 (3.9 and 2.9), respectively, and are no longer significantly different at the $1 \%$ level. This suggests that the two positions-related variables indeed are successful in capturing the effect of common preferences because, once they are included in the specification, the remaining information diffusion effect, which we attribute to word-of-mouth communication, is very comparable across investors that have stock portfolios very similar to their neighbors and those with portfolios that are quite different.

Finally, we revisit the analysis that relates industry-level returns prevailing over the next period to current information diffusion effects and a number of controls such as industries' current performance, individual investors' demand for stocks at the industry level, as well industry and quarter effects. As discussed earlier, it may be important to differentiate among the word-of-mouth effect and other sources of correlated purchases because they likely have different levels of influence on the market. Toward that goal, we augment the specification from Equation (5) by including two components of non-local diffusion - the word-of-mouth component and other information diffusion (expressed as the difference between the overall information diffusion effect and the estimate of word-of-mouth communication): ${ }^{11}$ The regression at the quarterly horizon is specified as follows:

$$
R_{q+1, i}=\beta_{W O M}^{N L} W \hat{O} M_{t, i}^{N L}+\beta_{O D}^{N L} O \hat{D}_{t, i}^{N L}+\beta_{R} R_{q, i}+\beta_{B S I} B S I_{t, i}+\sum_{t=1}^{23} \gamma_{t} D_{t}+\sum_{i=1}^{14} \delta_{i} D_{i}+\varepsilon_{t, i}
$$

where the first two regressors are the quarterly industry-level non-local information diffusion estimates of word-of-mouth effects ("WOM") and other information diffusion effects ("OD"), and the remaining regressors are the same as in Equation (5). Once again, the annual regression differs only in regard to the horizon of future industry-level returns (i.e., the left-hand-side variable) - those returns stretch across the next four quarters.

Panel A of Table XII presents results for the regression involving quarterly industry-level returns, while Panel B presents the one-year return regression results. Disentangling the overall

\footnotetext{
${ }^{11}$ The word-of-mouth component is defined as the diffusion effect that remains after controlling for preferences and the structure of the local economy.
} 
information diffusion effect into word-of mouth communication and other diffusion effects yields further insight as to how correlated trading among individuals may influence stock prices. The significant relation between non-local diffusion and subsequent industry-level returns appears to be driven by the word-of-mouth component. Across all specifications and all return horizons, word-of-mouth communication is predictive of higher future industry-level returns, while there is no significant relation between the other diffusion effects and returns. This result is consistent with the hypothesis that word-of-mouth communication creates a more dynamic exchange of information that may lead to a ripple effect of further information dissemination, which in turn may eventually impact stock prices.

\section{Conclusion}

Using a detailed set of common-stock investments that nearly 36,000 households made in the period from 1991 to 1996, we focus on the relation between the investment choices made by an individual investor's neighborhood (households located within 50 miles from the investor) and the investor's own investment choices. We find strong evidence of information diffusion: baseline estimates suggest that a ten percentage-point increase in purchases of stocks from an industry made by a household's neighbors is associated with a two percentage point increase in the household's own purchases of stocks from that industry, with the effect larger for local stock purchases.

The findings are robust to controls for inside information effects, domination of a single company (industry) in the neighborhood, and household fixed effects. In sum, there is strong evidence that individuals' purchasing decisions are related to those made by their neighbors. The strength of the information diffusion effect is compelling; for example, investors in more populous areas, where, on average, there are many more local investment choices, still are very concentrated in their purchases. To the extent that their investment choices are related to their neighbors', the information diffusion effect is likely at least partially responsible for individual investors' lack of diversification.

We further find that there is considerable heterogeneity among information diffusion effects across industries and across time and relate these patterns in individual investors' trading (i.e., quarters with high information diffusion) to future returns. We find that, even after controlling for aggregate individual investors' demand (as captured by the buy-sell imbalance) 
and past industry-level performance, information diffusion among non-local investors predicts future industry-level returns: an increase in non-local information diffusion equal to the interquartile range of the estimates of information diffusion across 322 industry-quarter observations is associated with a two to three percentage point increase in industry returns over the following year.

These findings are consistent with the hypothesis that there is a pronounced intertemporal dynamic of the flow of investment-relevant information between local and non-local investors, wherein the value-relevant information generated locally is disseminated over time to non-local investors. It appears that it requires a coordinated action of non-local investors (relative to any location, non-local investors clearly constitute the vast majority of all investors), who act upon the information disseminated to them by local investors, to move the asset prices during the next quarter or year. We propose and present evidence consistent with a mechanism that could generate the predictability of industry-level returns from non-local information diffusion. 


\section{References}

Banerjee, A., 1992, A simple model of herd behavior, Quarterly Journal of Economics 107, 797817.

Barber, Brad, and Terrance Odean, 2000, Trading is hazardous to your wealth: The common stock investment performance of individual investors, Journal of Finance 55, 773-806.

Barber, Brad, and Terrance Odean, 2002, All that glitters: The effect of attention on the buying behavior of individual and institutional investors. Working paper, UC Davis and UC Berkeley.

Barber, Brad, Terrance Odean, and Zhu, Ning, 2003, Systematic noise. Working paper, UC Davis and UC Berkeley.

Bernheim, B. Douglas, 1994, A Theory of Conformity, Journal of Political Economy 102, 84177.

Campbell, John Y.and John H. Cochrane, 1999, By Force of Habit: A Consumption-Based Explanation of Aggregate Stock Market Behavior, Journal of Political Economy 107, 205-51.

Carhart, Mark M., 1997, On persistence in mutual fund performance, Journal of Finance 52, 5782.

Coval, Joshua D., and Tobias J. Moskowitz, 1999, Home bias at home: Local equity preference in domestic portfolios, Journal of Finance 54, 1-39.

Coval, Joshua D., and Tobias J. Moskowitz, 2001, The geography of investment: Informed trading and asset prices, Journal of Political Economy 109(4), 811-841.

Duflo, Esther, and Emmanuel Saez, 2002, Participation and investment decisions in a retirement plan: the influence of colleagues' choices, Journal of Public Economics 85, 121-148.

Duflo, Esther, and Emmanuel Saez, 2003, The role of information and social interactions in retirement plan decisions: Evidence from a randomized experiment, The Quarterly Journal of Public Economics 118(3), 815-842.

Ellison, G., and D. Fudenberg, 1993, Rules of thumb for social learning, Journal of Political Economy CI, 93-126. 
Ellison, G., and D. Fudenberg, 1995, Word of mouth communication and social learning, Quarterly Journal of Economics 110, 93-125.

Fama, Eugene, and Kenneth French, 1993, Common risk factors in the return on bonds and stocks, Journal of Financial Economics 33, 3-53.

Feng, Fei, and Mark Seasholes, 2004, Herding and location, Journal of Finance, forthcoming.

Grinblatt, Mark and Matti Keloharju, 2001, How distance, language, and culture influence stockholdings and trades, Journal of Finance 56(3), 1053-1073.

Hong, Harrison, Jeffrey D. Kubik, and Jeremy C. Stein, 2003, Thy neighbor's portfolio: Wordof-mouth effects in the holdings and trades of money managers, Working paper, Princeton University, Syracuse University, and Harvard.

Hong, Harrison, Jeffrey D. Kubik, and Jeremy C. Stein, 2004, Social interaction and stockmarket participation, Journal of Finance, forthcoming.

Ivković, Zoran, and Scott Weisbenner, 2004, Local does as local is: Information content of the geography of individual investors' common stock investments, Journal of Finance, forthcoming.

Lakonishok, Josef, Andrei Shleifer, and Robert W. Vishny, 1992, The impact of institutional trading on stock prices, Journal of Financial Economics 32(1), 23-43.

Massa, Massimo, and Andrei Simonov, 2003, Hedging, stock market participation and portfolio choice, Working paper, INSEAD.

Odean, Terrance, 1998. Are investors reluctant to realize their losses? Journal of Finance 53, 1775-1179.

Shore, Stephen H., and Joshua White, External Habit Formation and the Home Bias Puzzle, Working Paper, 2003.

U.S. Census Bureau: Gazetteer Place and Zip Code Database.

Zhu, Ning, 2002, The local bias of individual investors, Working paper, Yale School of Management. 


\section{Table I: Quarterly Purchases of Stock by Households 1/1991 - 9/1996}

Table I summarizes quarterly household stock purchases at the industry level. Summary statistics are reported for the entire sample period (bottom row of the table) as well as annually. The first column presents the number of household, quarter, industry $(h, t, i)$ combinations in a given year for which household $h$ made at least one purchase in quarter $t$ in industry $i$. The second column tallies the number of distinct households appearing in the sample in a given year. The third column lists average dollar values of households' quarterly purchases, where median values are reported in parentheses directly underneath the mean values. The last two columns break down the purchases according to their distance from the household (i.e., whether the firm headquarters is located within 50 miles of the household) and their S\&P 500 status.

\begin{tabular}{|c|c|c|c|c|c|}
\hline & \# Purchases & \# Distinct HHs & $\begin{array}{c}\text { Mean Quarterly } \\
\text { purchase (in \$) } \\
\text { [Median] }\end{array}$ & $\%$ Local & $\%$ S\&P 500 \\
\hline 1991 & 36,250 & 20,366 & $\begin{array}{c}23,242 \\
{[7,113]}\end{array}$ & 16.4 & 47.9 \\
\hline 1992 & 36,270 & 20,300 & $\begin{array}{c}23,576 \\
{[7,500]}\end{array}$ & 17.0 & 48.7 \\
\hline 1993 & 34,377 & 18,894 & $\begin{array}{c}25,150 \\
{[7,500]}\end{array}$ & 16.4 & 46.5 \\
\hline 1994 & 28,726 & 16,307 & $\begin{array}{c}25,418 \\
{[7,388]}\end{array}$ & 17.4 & 43.3 \\
\hline 1995 & 30,299 & 16,134 & $\begin{array}{c}38,540 \\
{[9,313]}\end{array}$ & 17.8 & 43.5 \\
\hline $\begin{array}{l}1996 \\
(\mathrm{Q} 1-\mathrm{Q} 3)\end{array}$ & 25,364 & 15,483 & $\begin{array}{c}42,277 \\
{[9,725]}\end{array}$ & 17.5 & 43.5 \\
\hline TOTAL & 191,286 & 35,673 & $\begin{array}{l}28,922 \\
{[7,949]}\end{array}$ & 17.1 & 45.8 \\
\hline
\end{tabular}




\section{Table II: Information Diffusion and Stock Purchases, Local/Non-Local and S\&P 500/Non-S\&P 500 Breakdown, Pooled Regression 1/1991 - 9/1996}

The table presents the results of fitting the regression from Equation (2) for various dependent variables as follows:

$$
f_{h, t, i}=\beta F_{-h, t, i}^{50}+\sum_{t=1}^{23} \sum_{i=1}^{14} \gamma_{t, i} D_{t, i}+\text { other covariates }+\varepsilon_{h, t, i} .
$$

Panel A focuses on the entire universe of stocks, whereas Panels B and C presents results only for S\&P 500 and non-S\&P 500 stocks, respectively. Within each panel, every row pertains to a different left hand side variable. The first row pertains to the industry share breakdown $f_{h, t, i}$ computed across all buys and the next two rows pertain to the industry composition breakdowns computed across local purchases only and non-local purchases only, respectively. In the regressions for local buys we discarded all the $h, t, i$ observations for which there were no firms in industry $i$ within 50 miles from household $h$ in quarter $t$ because the household simply could not invest into industry $i$ locally.

\begin{tabular}{|c|c|c|c|}
\hline Sample & $\begin{array}{c}\text { Composition of Buys of } \\
\text { Households within } 50 \text { Miles }\end{array}$ & $R^{2}$ & \#Observations \\
\hline \multicolumn{4}{|c|}{ Panel A: All Stocks } \\
\hline All Buys & $\begin{array}{l}20.7^{* * *} \\
(0.3)\end{array}$ & 0.142 & $2,678,004$ \\
\hline $\begin{array}{l}\text { Local Buys } \\
\text { (within } 50 \text { miles) }\end{array}$ & $\begin{array}{l}119.3^{* * *} \\
(1.2)\end{array}$ & 0.232 & 568,247 \\
\hline $\begin{array}{l}\text { Non-Local Buys } \\
\text { (outside } 50 \text { miles) }\end{array}$ & $\begin{array}{l}8.4^{* * *} \\
(0.3)\end{array}$ & 0.129 & $2,337,314$ \\
\hline \multicolumn{4}{|c|}{ Panel B: S\&P 500 Stocks } \\
\hline All Buys & $\begin{array}{l}21.1^{* * *} \\
(0.5)^{4}\end{array}$ & 0.151 & $1,490,342$ \\
\hline $\begin{array}{l}\text { Local Buys } \\
\text { (within } 50 \text { miles) }\end{array}$ & $\begin{array}{l}156.1^{* * *} \\
(1.9)^{2}\end{array}$ & 0.287 & 235,657 \\
\hline $\begin{array}{l}\text { Non-Local Buys } \\
\text { (outside } 50 \text { miles) }\end{array}$ & $\begin{array}{l}9.0^{* * *} \\
(0.5)\end{array}$ & 0.138 & $1,327,438$ \\
\hline
\end{tabular}

Panel C: Non-S\&P 500 Stocks

\begin{tabular}{lccc}
\hline All Buys & $19.7^{* * *}$ & 0.136 & $1,752,198$ \\
& $(0.4)$ & & \\
Local Buys & $104.2^{* * *}$ & 0.226 & 377,244 \\
(within 50 miles) & $(1.4)$ & & \\
$\begin{array}{l}\text { Non-Local Buys } \\
\text { (outside 50 miles) }\end{array}$ & $6.9^{* * *}$ & 0.122 & $1,479,142$ \\
\hline
\end{tabular}

${ }^{* * *},{ }^{* *},{ }^{*}$ denote significance at the 1 percent, 5 percent, and 10 percent levels, respectively. 
Table III: Lags in Information Diffusion

This table presents results of fitting four regression specifications that allow for lags of information diffusion effects of up to four quarters. For the purposes of these analyses, we explicitly compute for each household $h$ and quarter $t$ the share of stock purchases across industries for all households except household $h$ in quarter $t, F_{-h, t, i}^{A l l}, i=1,2, \ldots, 14$, and run the following regression (Equation (3)):

$$
f_{h, t, i}=\beta_{0} F_{-h, t, i}^{50}+\beta_{0}^{A l l} F_{-h, t, i}^{A l l}+\sum_{j=1}^{4} \beta_{-j} F_{-h, t-j, i}^{50}+\sum_{j=1}^{4} \beta_{-j}^{A l l} F_{-h, t-j, i}^{A l l}+\varepsilon_{h, t, i}
$$

The four columns present results of running specifications with varying explanatory variables: contemporaneous only in (1), lagged by one quarter only in (2), both contemporaneous and lagged by one quarter in (3), and both contemporaneous and lagged by up to four quarters in (4).

\begin{tabular}{|c|c|c|c|c|}
\hline & (1) & (2) & (3) & (4) \\
\hline $\begin{array}{l}\text { Purchases of Households } \\
\text { within } 50 \text { miles (contemporaneous) }\end{array}$ & $\begin{array}{l}22.1^{* * *} \\
(0.3)\end{array}$ & & $\begin{array}{l}16.5^{* * *} \\
(0.4)\end{array}$ & $\begin{array}{l}11.7^{* * *} \\
(0.4)\end{array}$ \\
\hline $\begin{array}{l}\text { Purchases of Households } \\
\text { within } 50 \text { miles ( } 1 \text { quarter lag) }\end{array}$ & & $\begin{array}{l}21.1^{* * *} \\
(0.4)\end{array}$ & $\begin{array}{l}14.0^{* * *} \\
(0.4)\end{array}$ & $\begin{array}{l}8.3^{* * *} \\
(0.4)\end{array}$ \\
\hline $\begin{array}{l}\text { Purchases of Households } \\
\text { within } 50 \text { miles ( } 2 \text { quarter lag) }\end{array}$ & & & & $\begin{array}{l}6.2^{* * *} \\
(0.4)\end{array}$ \\
\hline $\begin{array}{l}\text { Purchases of Households } \\
\text { within } 50 \text { miles ( } 3 \text { quarter lag) }\end{array}$ & & & & $\begin{array}{l}6.8^{* * *} \\
(0.4)\end{array}$ \\
\hline $\begin{array}{l}\text { Purchases of Households } \\
\text { within } 50 \text { miles ( } 4 \text { quarter lag) }\end{array}$ & & & & $\begin{array}{l}8.2^{* * *} \\
(0.4)\end{array}$ \\
\hline $\begin{array}{l}\text { Purchases of all Households } \\
\text { (contemporaneous) }\end{array}$ & $\begin{array}{l}59.5^{* * *} \\
(0.4)\end{array}$ & & $\begin{array}{l}42.9^{* * *} \\
(1.4)\end{array}$ & $\begin{array}{l}40.4^{* * *} \\
(1.6)\end{array}$ \\
\hline $\begin{array}{l}\text { Purchases of all Households } \\
\text { (1 quarter lag) }\end{array}$ & & $\begin{array}{l}61.5^{* * *} \\
(0.4)\end{array}$ & $(1.4)^{* * *}$ & $\begin{array}{l}-10.1^{* * *} \\
(1.9)^{2}\end{array}$ \\
\hline $\begin{array}{l}\text { Purchases of all Households } \\
\text { ( } 2 \text { quarter lag) }\end{array}$ & & & & $\begin{array}{l}8.5^{* * *} \\
(1.8)\end{array}$ \\
\hline $\begin{array}{l}\text { Purchases of all Households } \\
\text { ( } 3 \text { quarter lag) }\end{array}$ & & & & $\begin{array}{r}-2.6 \\
(1.8)\end{array}$ \\
\hline $\begin{array}{l}\text { Purchases of all Households } \\
\text { (4 quarter lag) }\end{array}$ & & & & $\begin{array}{l}8.4^{* * *} \\
(1.5)\end{array}$ \\
\hline $\mathrm{R}^{2}$ & 0.136 & 0.139 & 0.142 & 0.152 \\
\hline Number of observations & $2,678,004$ & $2,570,848$ & $2,570,848$ & $2,170,504$ \\
\hline
\end{tabular}

${ }^{* * * *},{ }^{* *},{ }^{*}$ denote significance at the 1 percent, 5 percent, and 10 percent levels, respectively. 


\section{Table IV: Information Diffusion and Population}

This table presents results of stratifying households according to the size of the population that resides within 50 miles from the household into four categories and assessing information diffusion effects in neighborhoods of various size by running the following regression (a variant of Equation (2)):

$f_{h, t, i}=\left(\beta F_{-h, t, i}^{50}\right) *$ Population Interactions $+\left(\sum_{t=1}^{23} \sum_{i=1}^{14} \gamma_{t, i} D_{t, i}\right) *$ Population Interactions $+\varepsilon_{h, t, i}$.

The four categories are: 0-1 million, 1-2.5 million, 2.5-5 million, and more than 5 million residents (the latter includes households in and around New York City, Los Angeles, and Chicago). Regressions are estimated on subsamples selected by the type of purchase and presented in three panels accordingly (All Buys, Local Buys, and Non-Local Buys). The coefficient estimate presented in the table for a particular population group represents the overall information diffusion effect for that group (i.e., the sum of the diffusion effect for the $0-1$ million group and the interaction term for that particular population group).

\begin{tabular}{|c|c|c|c|}
\hline Population (in 000s) & $\begin{array}{c}\text { Composition of } \\
\text { HH Buys } \leq 50 \text { miles }\end{array}$ & $\mathrm{R}^{2}$ & \# obs. \\
\hline \multicolumn{4}{|c|}{ Panel A: All Buys } \\
\hline $0-1,000$ & $\begin{array}{l}5.2^{* * *} \\
(0.4)\end{array}$ & 0.147 & $2,678,004$ \\
\hline $1,000-2,500$ & $\begin{array}{l}10.7^{* * *} \\
(0.8)\end{array}$ & & \\
\hline $2,500-5,000$ & $\begin{array}{l}27.2^{* * *} \\
(1.0)\end{array}$ & & \\
\hline $\begin{array}{l}5,000+ \\
\text { (NY, LA, Chicago) }\end{array}$ & $\begin{array}{l}53.5^{* * *} \\
(0.9)\end{array}$ & & \\
\hline
\end{tabular}

\begin{tabular}{|c|c|c|c|}
\hline \multicolumn{4}{|c|}{ Panel B: Local Buys } \\
\hline $0-1,000$ & $\begin{array}{l}64.2^{\text {**** }} \\
(4.9)\end{array}$ & 0.245 & 568,247 \\
\hline $1,000-2,500$ & $\begin{array}{l}59.0^{* * *} \\
(3.0)\end{array}$ & & \\
\hline $2,500-5,000$ & $\begin{array}{l}102.7^{* * *} \\
(2.3)\end{array}$ & & \\
\hline $\begin{array}{l}5,000+ \\
(\mathrm{NY}, \mathrm{LA}, \text { Chicago) }\end{array}$ & $\begin{array}{l}139.5^{* * *} \\
(1.6)\end{array}$ & & \\
\hline \multicolumn{4}{|c|}{ Panel C: Non-Local Buys } \\
\hline $0-1,000$ & $\begin{array}{l}4.5^{* * *} \\
(0.4)\end{array}$ & 0.129 & $2,337,314$ \\
\hline $1,000-2,500$ & $\begin{array}{l}6.5^{* * *} \\
(0.8)\end{array}$ & & \\
\hline $2,500-5,000$ & $\begin{array}{l}9.3^{* * *} \\
(1.1)^{-1}\end{array}$ & & \\
\hline $\begin{array}{l}5,000+ \\
\text { (NY, LA, Chicago) }\end{array}$ & $\begin{array}{l}13.1^{* * *} \\
(1.0)\end{array}$ & & \\
\hline
\end{tabular}

${ }^{* * *},{ }^{* *},{ }^{*}$ denote significance at the 1 percent, 5 percent, and 10 percent levels, respectively. 


\section{Table V: Information Diffusion and Stock Purchases by Location}

This table reports results of exploring information diffusion effects among households in 25 major U.S. cities. We identify 25 large U.S. cities and collect the rest of investors into the $26^{\text {th }}$ "city" $R$ ("Rest of Investors") and run a regression wherein we relate the share of purchases across industries for each household with those of the residents of the same city and those of the residents of all other major cities and the rest of the investors (i.e., those that do not reside in one of the 25 cities):

$$
f_{h, t, i}=\sum_{c=1}^{25} \alpha_{c} F_{c-h, t, i} I(h \in c)+\sum_{c=1}^{26} \beta_{c} F_{c, t, i} I(h \notin c)+\varepsilon_{h, t, i} .
$$

The indicator function expression $I(h \in c)$ means that household $h$ resides in city $c$. For a given city $c, c=1, \ldots, 25,\left(\alpha_{c}-\beta_{c}\right)$ represents the effect of a change in industry allocation in city $c$ upon households in that city relative to households that live elsewhere. The first two columns focus on all buys. The weighted-average difference between the two information diffusion coefficients, that is, $\left(\alpha_{c}-\beta_{c}\right)$, is reported in the second to last row of the table. The next two pairs of columns replicate the same analysis for local purchases and non-local purchases. 
Table V: Information Diffusion and Stock Purchases by Location (continued)

\begin{tabular}{|c|c|c|c|c|c|c|}
\hline \multirow{2}{*}{ 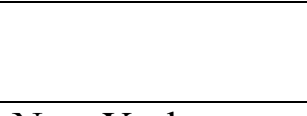 } & \multicolumn{2}{|c|}{ All Buys } & \multicolumn{2}{|c|}{ Local Buys } & \multicolumn{2}{|c|}{ Non-Local Buys } \\
\hline & Own City & Other & Own City & Other & Own City & Other \\
\hline New York & $32.7^{\text {**** }}$ & $3.0^{* *}$ & $83.9^{* * *}$ & -0.1 & $14.4^{* * *}$ & $4.1^{* * *}$ \\
\hline Los Angeles & $40.4^{* * *}$ & $8.4^{* * *}$ & $89.3^{* * *}$ & $12.3^{* * *}$ & $23.4^{* * *}$ & $8.7^{* * *}$ \\
\hline Chicago & $36.0^{* * *}$ & $5.0^{* * *}$ & $100.6^{* * *}$ & 3.2 & $15.5^{* * *}$ & $6.7^{* * *}$ \\
\hline Houston & $29.4^{* * *}$ & $3.0^{* * *}$ & $88.1^{* * *}$ & $-7.1^{* * *}$ & $13.6^{* * *}$ & $7.0^{* * *}$ \\
\hline Philadelphia & $31.2^{* * *}$ & $4.3^{* * *}$ & $93.5^{* * *}$ & $5.8^{* * *}$ & $10.9^{* * *}$ & $4.8^{* * *}$ \\
\hline Phoenix & $28.5^{* * *}$ & $-2.6^{* * *}$ & $76.3^{* * *}$ & $-8.5^{* * *}$ & $12.5^{* * *}$ & 0.5 \\
\hline San Diego & $37.1^{* * * *}$ & $4.5^{* * *}$ & $105.5^{* * *}$ & 1.8 & $15.3^{* * *}$ & $4.8^{* * *}$ \\
\hline Dallas & $32.2^{* * *}$ & $1.5^{* *}$ & $82.7^{* * *}$ & $3.5^{* * *}$ & $15.6^{* * *}$ & 1.3 \\
\hline San Antonio & $13.2^{* * *}$ & -0.1 & $24.8^{* * *}$ & $-0.9^{*}$ & 2.2 & 0.3 \\
\hline Detroit & $26.7^{* * *}$ & $-1.2^{* *}$ & $73.8^{* * *}$ & $-8.4^{* * *}$ & $11.2^{* * *}$ & $2.3^{* * *}$ \\
\hline San Jose & $58.1^{* * *}$ & 1.0 & $119.7^{* * *}$ & $6.4^{* * *}$ & $19.4^{* * *}$ & $-3.0^{* * *}$ \\
\hline Indianapolis & $30.0^{* * *}$ & $3.5^{* * *}$ & $80.5^{* * *}$ & $3.3^{* * *}$ & $10.9^{* * *}$ & $3.2^{* * *}$ \\
\hline San Francisco & $32.1^{* * *}$ & $-6.3^{* * *}$ & $101.5^{* * *}$ & $-13.6^{* * *}$ & $5.0^{* * *}$ & $-3.8^{* *}$ \\
\hline Jacksonville & $12.9^{* * *}$ & $1.0^{* * *}$ & $65.6^{* * *}$ & $2.2^{* * *}$ & -2.0 & 0.3 \\
\hline Columbus & $26.3^{* * *}$ & $3.2^{* * *}$ & $77.5^{* * *}$ & $2.4^{* * *}$ & $10.0^{* * *}$ & $3.4^{* * *}$ \\
\hline Baltimore & $26.9^{* * *}$ & -0.5 & $66.3^{* * *}$ & 1.3 & $11.0^{* * *}$ & 0.1 \\
\hline Milwaukee & $31.7^{* * *}$ & $3.4^{* * *}$ & $79.2^{* * *}$ & $5.0^{* * *}$ & $12.7^{* * *}$ & $2.6^{* * *}$ \\
\hline Boston & $25.7^{* * *}$ & $-0.6^{*}$ & $82.8^{* * *}$ & $-1.8^{* * *}$ & $7.7^{* * *}$ & 0.2 \\
\hline Denver & $31.9^{* * *}$ & $2.7^{* * *}$ & $95.9^{* * *}$ & 1.2 & $13.0^{* * *}$ & $4.5^{* * *}$ \\
\hline Kansas City & $30.1^{* * *}$ & $5.1^{* * *}$ & $109.3^{* * *}$ & $11.1^{* * *}$ & $5.4^{* * *}$ & $3.8^{* * *}$ \\
\hline Atlanta & $34.5^{* * *}$ & 0.6 & $90.2^{* * *}$ & $2.2^{* *}$ & $14.0^{* * *}$ & -0.1 \\
\hline Minneapolis & $33.8^{* * *}$ & $6.8^{* * *}$ & $72.2^{* * *}$ & $2.8^{*}$ & $22.1^{* * *}$ & $8.2^{* * *}$ \\
\hline Miami & $25.9^{* * *}$ & $3.7^{* * *}$ & $82.9^{* * *}$ & $3.7^{* * *}$ & $7.3^{* * *}$ & $4.1^{* * *}$ \\
\hline Tampa & $14.9^{* * *}$ & $-2.2^{* * *}$ & $53.2^{* * *}$ & -1.4 & -0.9 & $-1.8^{* *}$ \\
\hline Rest of Investors & & $13.5^{* * *}$ & & $-26.2^{* * *}$ & & $20.1^{* * *}$ \\
\hline $\begin{array}{l}\text { Average Diff. } \\
\text { (Own -Other) }\end{array}$ & $\begin{array}{l}35.0 \\
(0.7)\end{array}$ & & $\begin{array}{l}97.9 \\
(1.4)\end{array}$ & & $\begin{array}{l}10.5 \\
(0.8\end{array}$ & \\
\hline $\mathrm{R}^{2}$ & 0.1 & & 0.3 & & 0.13 & \\
\hline \# observations & 1,20 & & 403, & & 984, & \\
\hline
\end{tabular}

${ }^{* * *},{ }^{* *},{ }^{*}$ denote significance at the 1 percent, 5 percent, and 10 percent levels, respectively. 


\section{Table VI: Information Diffusion and Stock Purchases by Industry}

The table presents regression results based on specifications similar to Equation 2, carried out separately for each industry. Two specifications are fitted for each industry. The first specification employed for each industry is very similar to the baseline specification, outlined in Equation (2), with only 23 quarter-dummies and without any additional controls. In the second specification we include 15 style controls that capture household investment style as follows:

$$
f_{h, t}=\beta F_{-h, t}^{50}+\sum_{t=1}^{23} \gamma_{t} D_{t}+\text { style controls }+\varepsilon_{h, t} .
$$

The 15 style controls account for a household's preference to invest in stocks with certain characteristics (for example, in high-momentum, small, low book-to-market firms). Regressions are fitted for samples of all buys, local buys, and non-local buys. For each of the three samples, the first column shows the results of fitting the first, baseline specification, and the second column shows the results of fitting the second specification that includes 15 style controls.

\begin{tabular}{|c|c|c|c|c|c|c|}
\hline \multirow[b]{2}{*}{ Industry } & \multicolumn{2}{|c|}{ All Buys } & \multicolumn{2}{|c|}{ Local Buys } & \multicolumn{2}{|c|}{ Non-Local Buys } \\
\hline & Baseline & $\begin{array}{c}\text { Style } \\
\text { Dummies }\end{array}$ & Baseline & $\begin{array}{c}\text { Style } \\
\text { Dummies }\end{array}$ & Baseline & $\begin{array}{c}\text { Style } \\
\text { Dummies }\end{array}$ \\
\hline Mining & $4.3^{* * *}$ & $4.3^{* * *}$ & $18.7^{* * *}$ & $20.2^{* * *}$ & $3.2^{*}$ & $3.3^{* *}$ \\
\hline Oil \& Gas & $1.6^{* *}$ & $1.6^{* *}$ & $92.0^{* * *}$ & $88.3^{* * *}$ & 0.7 & 0.7 \\
\hline Construction & 0.8 & 1.0 & $78.2^{* * *}$ & $79.3^{* * *}$ & -0.4 & -0.1 \\
\hline Food & $3.6^{* * *}$ & $3.3^{* * *}$ & $63.1^{* * *}$ & $57.1^{* * *}$ & 0.1 & 0.0 \\
\hline Basic Materials & $5.9^{* * *}$ & $5.7^{* * *}$ & $63.2^{* * *}$ & $62.4^{* * *}$ & $2.5^{* *}$ & $2.4^{* *}$ \\
\hline Medical/Biotech & $10.4^{* * *}$ & $11.3^{* * *}$ & $84.3^{* * *}$ & $90.4^{* * *}$ & $4.3^{* * *}$ & $4.5^{* * *}$ \\
\hline Manufacturing & $6.7^{* * *}$ & $5.9^{* * *}$ & $57.3^{* * *}$ & $54.0^{* * *}$ & $1.6^{*}$ & 1.3 \\
\hline Transportation & $6.1^{* * *}$ & $6.3^{* * *}$ & $80.5^{* * *}$ & $88.1^{* * *}$ & $2.8^{* * *}$ & $2.7^{* * *}$ \\
\hline Telecom & $3.7^{* * *}$ & $3.1^{* * *}$ & $44.2^{* * *}$ & $44.8^{* * *}$ & 0.8 & 0.4 \\
\hline Utilities & $7.5^{* * *}$ & $6.4^{* * *}$ & $88.8^{* * *}$ & $87.7^{* * *}$ & $5.0^{* * *}$ & $3.9^{* * *}$ \\
\hline Retail Trade & $20.1^{* * *}$ & $19.5^{* * *}$ & $117.4^{* * *}$ & $117.4^{* * *}$ & $11.7^{* * *}$ & $11.4^{* * *}$ \\
\hline Financial & $7.8^{* * *}$ & $5.7^{* * *}$ & $83.2^{* * *}$ & $62.9^{* * *}$ & $2.8^{* * *}$ & $2.2^{* *}$ \\
\hline Technology & $36.7^{* * *}$ & $35.3^{* * *}$ & $140.7^{* * *}$ & $136.4^{* * *}$ & $14.6^{* * *}$ & $14.0^{* * *}$ \\
\hline Services & $13.0^{* * *}$ & $10.6^{* * *}$ & $135.2^{* * *}$ & $132.5^{* * *}$ & $5.4^{* * *}$ & $4.2^{* * *}$ \\
\hline
\end{tabular}

${ }^{* * * *},{ }^{* *},{ }^{*}$ denote significance at the 1 percent, 5 percent, and 10 percent levels, respectively. 
Table VII: Dispersion in Quarterly Information Diffusion by Industry (1/1991 - 9/1996)

The table presents summary statistics of regression estimates $\beta$ in specifications similar to Equation 2, carried out for each quarter $t$ and each industry $i$ as follows:

$$
f_{h}=\beta F_{-h}^{50}+\varepsilon_{h} .
$$

Thus, summary statistics obtained by running industry-by-industry regressions separately for each of the 23 quarters, for a total of 322 estimates. Regressions are fitted for all buys, local buys, and non-local buys, with the means, medians, and the interquartile ranges of the information diffusion coefficients reported for each industry (the first fourteen rows of the table). Finally, the last row of the table presents summary statistics across all industries, that is, across all 322 estimates of the information diffusion coefficient $\beta$.

\begin{tabular}{|c|c|c|c|c|c|c|c|c|c|}
\hline \multirow{2}{*}{ Industry } & \multicolumn{3}{|c|}{ All Buys } & \multicolumn{3}{|c|}{ Local Buys } & \multicolumn{3}{|c|}{ Non-Local Buys } \\
\hline & Mean & Median & $25^{\text {th }}-75^{\text {tho }} \%$ & Mean & Median & $25^{\text {th }}-75^{\text {th }} \%$ & Mean & Median & $25^{t h}-75^{t h} \%$ \\
\hline Mining & 3.6 & 0.7 & $-2.0-6.6$ & 30.1 & 24.1 & $-12.8-61.9$ & 2.5 & -0.9 & $-2.6-5.3$ \\
\hline Oil \& Gas & 3.1 & 0.2 & $-1.6-5.3$ & 133.5 & 121.6 & $40.7-212.9$ & 1.5 & -0.7 & $-2.9-4.5$ \\
\hline Construction & 0.6 & 0.3 & $-2.0-4.2$ & 125.0 & 54.0 & $-26.2-148.3$ & -1.5 & -1.8 & $-4.5-0.2$ \\
\hline Food & 3.2 & 2.9 & $0.5-4.8$ & 90.6 & 63.5 & $34.1-124.9$ & 0.0 & 0.4 & $-2.1-2.8$ \\
\hline Basic Materials & 5.2 & 3.7 & $1.2-10.2$ & 84.6 & 62.2 & $31.4-124.9$ & 1.8 & 0.2 & $-2.0-6.4$ \\
\hline Medical/Biotech & 10.0 & 10.0 & $5.6-13.4$ & 73.8 & 67.3 & $37.7-106.5$ & 4.7 & 3.5 & $0.3-7.8$ \\
\hline Manufacturing & 7.5 & 6.6 & $5.4-12.1$ & 73.1 & 56.7 & $37.8-105.9$ & 2.2 & 1.9 & $-0.3-6.4$ \\
\hline Transportation & 5.8 & 3.9 & $0.3-13.0$ & 98.0 & 63.4 & $22.1-155.1$ & 2.4 & 1.8 & $-2.3-6.7$ \\
\hline Telecom & 3.6 & 2.1 & $-0.8-9.0$ & 50.2 & 44.9 & $9.4-74.6$ & 1.4 & -0.7 & $-3.9-6.0$ \\
\hline Utilities & 7.1 & 6.0 & $1.1-13.3$ & 90.9 & 72.8 & $19.4-109.9$ & 4.6 & 3.8 & $-0.0-7.8$ \\
\hline Retail Trade & 16.5 & 12.6 & $11.4-23.1$ & 113.1 & 114.1 & $83.7-131.7$ & 8.5 & 6.6 & $4.0-9.8$ \\
\hline Financial & 7.9 & 7.4 & $4.1-11.7$ & 92.9 & 105.1 & $58.3-129.4$ & 3.0 & 3.0 & $0.1-4.8$ \\
\hline Technology & 36.6 & 36.2 & $33.5-40.8$ & 143.7 & 140.6 & $128.3-152.5$ & 14.6 & 14.9 & $11.1-19.1$ \\
\hline Services & 13.9 & 13.5 & $7.1-19.6$ & 161.7 & 179.2 & $101.7-228.5$ & 6.0 & 6.0 & $-0.9-10.5$ \\
\hline All Industries & 8.9 & 6.1 & $1.0-13.1$ & 97.2 & 83.9 & $35.3-137.1$ & 3.7 & 2.6 & $-1.4-7.3$ \\
\hline
\end{tabular}




\section{Table VIII: Regression of Monthly Portfolio Returns 4/91 - 9/97 (in percentages), High vs. Low Diffusion Industries}

This table presents results of regressing zero-cost portfolio returns formed on the basis of estimates of industry-level quarterly information diffusion effects on four factors (Carhart (1997)). Each time series of monthly portfolio returns is based on equallyweighted monthly industry returns. At the end of each quarter, industry-level information diffusion coefficients $\beta$ are sorted by magnitude. The industries featuring the five highest coefficients (in some specifications, this group would exclude technology stocks if they ranked among the highest, a very common occurrence) are grouped into the "High Diffusion" portfolio, whereas the industries featuring the five lowest coefficients are grouped into the "Low Diffusion" portfolio. Portfolios are rebalanced either every three months or every twelve months (with partial changes to the portfolio every three months). The table reports regression results for zero-cost portfolios formed on the basis of the high- and low-diffusion portfolios.

\begin{tabular}{|c|c|c|c|c|c|c|c|c|c|}
\hline & \multicolumn{3}{|c|}{$\begin{array}{l}\text { High Minus Low } \\
\text { Diffusion }\end{array}$} & \multicolumn{3}{|c|}{$\begin{array}{l}\text { High Minus Low } \\
\text { Local Diffusion }\end{array}$} & \multicolumn{3}{|c|}{$\begin{array}{l}\text { High Minus Low } \\
\text { Non-Local Diffusion }\end{array}$} \\
\hline & 3-month & $\begin{array}{l}\text { 3-month } \\
\text { (no tech) }\end{array}$ & 12-month & 3-month & $\begin{array}{l}\text { 3-month } \\
\text { (no tech) }\end{array}$ & 12-month & 3-month & $\begin{array}{l}\text { 3-month } \\
\text { (no tech) }\end{array}$ & 12-month \\
\hline Market & $\begin{array}{c}0.14^{*} \\
(0.08)\end{array}$ & $\begin{array}{r}0.09 \\
(0.07)\end{array}$ & $\begin{array}{c}0.16^{* * *} \\
(0.05)\end{array}$ & $\begin{array}{r}0.05 \\
(0.06)\end{array}$ & $\begin{array}{r}0.04 \\
(0.06)\end{array}$ & $\begin{array}{c}0.09^{* *} \\
(0.04)\end{array}$ & $\begin{array}{r}0.11 \\
(0.08)\end{array}$ & $\begin{array}{r}0.07 \\
(0.08)\end{array}$ & $\begin{array}{c}0.13^{* * *} \\
(0.05)\end{array}$ \\
\hline Small minus Big & $\begin{array}{c}0.37^{* *} \\
(0.15)\end{array}$ & $\begin{array}{r}0.19 \\
(0.14)\end{array}$ & $\begin{array}{c}0.30^{* * *} \\
(0.09)\end{array}$ & $\begin{array}{c}0.15^{* *} \\
(0.06)\end{array}$ & $\begin{array}{r}0.02 \\
(0.07)\end{array}$ & $\begin{array}{r}0.07 \\
(0.05)\end{array}$ & $\begin{array}{r}0.19 \\
(0.18)\end{array}$ & $\begin{array}{r}0.09 \\
(0.18)\end{array}$ & $\begin{array}{c}0.26^{* *} \\
(0.11)\end{array}$ \\
\hline High minus Low & $\begin{array}{r}0.08 \\
(0.16)\end{array}$ & $\begin{array}{r}0.12 \\
(0.15)\end{array}$ & $\begin{array}{r}-0.06 \\
(0.11)\end{array}$ & $\begin{array}{r}-0.11 \\
(0.08)\end{array}$ & $\begin{array}{r}-0.09 \\
(0.07)\end{array}$ & $\begin{array}{r}-0.12 \\
(0.07)\end{array}$ & $\begin{array}{r}0.08 \\
(0.15)\end{array}$ & $\begin{array}{r}0.13 \\
(0.15)\end{array}$ & $\begin{array}{r}0.01 \\
(0.11)\end{array}$ \\
\hline Up minus Down & $\begin{array}{r}-0.09 \\
(0.10)\end{array}$ & $\begin{array}{l}-0.05 \\
(0.10)\end{array}$ & $\begin{array}{r}-0.07 \\
(0.06)\end{array}$ & $\begin{array}{l}-0.26^{* * *} \\
(0.08)\end{array}$ & $\begin{array}{l}-0.25^{* * *} \\
(0.09)\end{array}$ & $\begin{array}{l}-0.21^{* * *} \\
(0.07)\end{array}$ & $\begin{array}{r}-0.12 \\
(0.11)\end{array}$ & $\begin{array}{l}-0.04 \\
(0.11)\end{array}$ & $\begin{array}{l}-0.02 \\
(0.05)\end{array}$ \\
\hline $\begin{array}{l}p \text {-value of } \\
\text { regression }\end{array}$ & $0.099^{*}$ & 0.647 & $0.000^{* * *}$ & $0.003^{* * *}$ & $0.049^{* *}$ & $0.000^{* * *}$ & 0.665 & 0.907 & $0.001^{* * *}$ \\
\hline Alpha & $\begin{array}{r}0.26 \\
(0.22)\end{array}$ & $\begin{array}{r}0.27 \\
(0.21)\end{array}$ & $\begin{array}{r}0.18 \\
(0.16)\end{array}$ & $\begin{array}{r}0.19 \\
(0.17)\end{array}$ & $\begin{array}{r}0.07 \\
(0.17)\end{array}$ & $\begin{array}{l}0.31 \\
(0.12)\end{array}$ & $\begin{array}{c}0.45^{* * *} \\
(0.17)\end{array}$ & $\begin{array}{r}0.44^{* *} \\
(0.20)\end{array}$ & $\begin{array}{r}0.23 \\
(0.13)\end{array}$ \\
\hline Raw Return & $\begin{array}{r}0.36 \\
(0.25)\end{array}$ & $\begin{array}{c}0.36^{*} \\
(0.22)\end{array}$ & $\begin{array}{r}0.29 \\
(0.20)\end{array}$ & $\begin{array}{r}-0.05 \\
(0.19)\end{array}$ & $\begin{array}{r}-0.18 \\
(0.21)\end{array}$ & $\begin{array}{r}0.17 \\
(0.19)\end{array}$ & $\begin{array}{r}0.48^{* *} \\
(0.23)\end{array}$ & $\begin{array}{c}0.53 \\
(0.27)\end{array}$ & $\begin{array}{c}0.39 \\
(0.19)\end{array}$ \\
\hline
\end{tabular}

${ }^{* * * *},{ }^{* *},{ }^{*}$ denote significance at the 1 percent, 5 percent, and 10 percent levels, respectively. 
Table IX: Information Diffusion and Future Stock Returns Across Industries

This table presents panel regression results of relating industry-level returns prevailing over the next period to current information diffusion effects, industries' current performance, individual investors' demand for stocks at the industry level, as well industry and quarter effects. The regression at the quarterly horizon (Panel A) is specified as follows (Equation (5)):

$$
R_{q+1, i}=\beta_{I D}^{N L} I \hat{D}_{t, i}^{N L}+\beta_{R} R_{q, i}+\beta_{B S I} B S I_{t, i}+\sum_{t=1}^{23} \gamma_{t} D_{t}+\sum_{i=1}^{14} \delta_{i} D_{i}+\varepsilon_{t, i} .
$$

The first regressor is the quarterly industry-level non-local information diffusion estimate, the second regressor is the lagged industrylevel return, the third regressor is the industry-level demand, and the remaining regressors are controls for industry and quarter effects. The industry-level demand is computed as the difference between buys and sells of stock in the given industry divided by their sum: $B S I_{t, i}=\left(\$\right.$ Buys $_{t, i}-\$$ Sells $\left._{t, i}\right) /\left(\$\right.$ Buys $_{t, i}+\$$ Sells $\left._{t, i}\right)$. The annual regression (Panel B) differs only in regard to the horizon of future industry-level returns (i.e., the left-hand-side variable) - those returns stretch across the next four quarters. Each of the three specifications introduces increasingly more controls, culminating in columns (3) and (6) that feature the full set of control variables from Equation (5).

\begin{tabular}{|c|c|c|c|c|c|c|}
\hline & \multicolumn{3}{|c|}{$\begin{array}{c}\text { Panel A: } \\
\text { Dependent Variable }= \\
\text { Industry Return Over } \text { Quarter }_{t+1} \\
\text { (in percent) }\end{array}$} & \multicolumn{3}{|c|}{$\begin{array}{c}\text { Panel B: } \\
\text { Dependent Variable }= \\
\text { Industry Return Over Quarters }{ }_{t+1} \text { to } t+4 \\
\text { (in percent) }\end{array}$} \\
\hline & (1) & (2) & (3) & $(4)$ & (5) & (6) \\
\hline NON-LOCAL BUY Diffusion $_{t}$ & $\begin{array}{c}0.08^{*} \\
(0.04)\end{array}$ & $\begin{array}{l}0.08^{\text {** }} \\
(0.04)\end{array}$ & $\begin{array}{c}0.08^{* *} \\
(0.04)\end{array}$ & $\begin{array}{c}0.20^{*} \\
(0.12)\end{array}$ & $\begin{array}{c}0.22^{*} \\
(0.12)\end{array}$ & $\begin{array}{c}0.23^{*} \\
(0.12)\end{array}$ \\
\hline Return $_{t}$ & & $\begin{array}{r}0.07 \\
(0.07)\end{array}$ & $\begin{array}{r}0.08 \\
(0.07)\end{array}$ & & $\begin{array}{c}0.30^{* *} \\
(0.15)\end{array}$ & $\begin{array}{r}0.23 \\
(0.16)\end{array}$ \\
\hline Buy-Sell Imbalance $_{t}$ & & & $\begin{array}{r}0.01 \\
(0.03)\end{array}$ & & & $\begin{array}{c}-0.11 \\
(0.08)\end{array}$ \\
\hline Industry effects included? & Yes & Yes & Yes & Yes & Yes & Yes \\
\hline Quarter effects included? & Yes & Yes & Yes & Yes & Yes & Yes \\
\hline $\mathrm{R}^{2}$ & 0.569 & 0.570 & 0.570 & 0.495 & 0.503 & 0.508 \\
\hline \# of observations & 322 & 322 & 322 & 322 & 322 & 322 \\
\hline
\end{tabular}

,*** denote significance at the 1 percent, 5 percent, and 10 percent levels, respectively. 


\section{Table X: Regression of Monthly Portfolio Returns 2/91 - 12/96 (in percentages), Local vs. Non-Local Buys and Sales}

This table presents raw returns and risk-adjusted returns (using the four-factor model proposed by Carhart (1997)) of portfolio strategies based on the purchases and sales of local and non-local stocks that the individual investors made during the sample period. In Panel A, returns to the "Local" portfolio are constructed by value-weighting each month all the purchases of stocks local to the respective investors (i.e., headquartered within 50 miles from their residences) by the size of the purchase. Analogously, returns to the "Non-Local" portfolio are constructed by valueweighting each month all the purchases of stocks that are not local to the respective investors by the size of the purchase. Finally, the portfolio "Difference" is the zero-cost portfolio that is long the "Local" portfolio and short the "Non-Local" portfolio. Portfolios are rebalanced either every three months (left side of the panel) or every twelve months (right side of the panel) with partial changes to the portfolio every three months. The structure of Panel B is analogous to the structure of Panel A, except for the fact that the transactions that Panel B focuses on are stock sales.

\begin{tabular}{|c|c|c|c|c|c|c|}
\hline & \multicolumn{6}{|c|}{ Panel A: Buys } \\
\hline & \multicolumn{3}{|c|}{ Held in Portfolio for Three Months } & \multicolumn{3}{|c|}{ Held in Portfolio for One Year } \\
\hline & Local & Non-Local & Difference & Local & Non-Local & Difference \\
\hline Raw Return & $\begin{array}{c}1.60^{* * * *} \\
(0.57)\end{array}$ & $\begin{array}{c}1.17^{* *} \\
(0.53)\end{array}$ & $\begin{array}{l}0.44^{* * *} \\
(0.11)\end{array}$ & $\begin{array}{l}1.61^{\text {*** }} \\
(0.54)\end{array}$ & $\begin{array}{l}1.31^{* * *} \\
(0.48)\end{array}$ & $\begin{array}{c}0.30^{\text {*** }} \\
(0.11)\end{array}$ \\
\hline Alpha & $\begin{array}{r}0.03 \\
(0.32)\end{array}$ & $\begin{array}{l}-0.29 \\
(0.27)\end{array}$ & $\begin{array}{c}0.32^{* *} \\
(0.13)\end{array}$ & $\begin{array}{r}0.10 \\
(0.28)\end{array}$ & $\begin{array}{l}-0.08 \\
(0.22)\end{array}$ & $\begin{array}{r}0.18 \\
(0.12)\end{array}$ \\
\hline
\end{tabular}

Panel B: Sales

\begin{tabular}{lccccccc}
\hline & \multicolumn{2}{c}{ Held in Portfolio for Three Months } & & \multicolumn{2}{c}{ Held in Portfolio for One Year } \\
\cline { 2 - 3 } \cline { 7 - 8 } & Local & Non-Local & Difference & & Local & Non-Local & Difference \\
\hline \multirow{2}{*}{ Raw Return } & $1.57^{* * *}$ & $1.27^{* * *}$ & $0.30^{* * *}$ & & $1.68^{* * *}$ & $1.42^{* * *}$ & $0.26^{* *}$ \\
& $(0.54)$ & $(0.50)$ & $(0.11)$ & & $(0.52)$ & $(0.46)$ & $(0.12)$ \\
Alpha & & & & & & \\
& -0.09 & -0.29 & 0.20 & & 0.05 & -0.06 & 0.11 \\
& $(0.33)$ & $(0.26)$ & $(0.16)$ & & $(0.31)$ & $(0.20)$ & $(0.15)$ \\
\hline
\end{tabular}

${ }^{* * *},{ }^{* *},{ }^{*}$ denote significance at the 1 percent, 5 percent, and 10 percent levels, respectively. 


\section{Table XI: Information Diffusion, Correlated Preferences for Industry Allocation, and Structure of Local Economy}

This table presents results of assessing the contribution of word-of-mouth effects to the overall information diffusion effect. Toward that goal, we regress households' industry-level purchases on neighbors' purchases, variables capturing correlated preferences for industry allocation, variables capturing the structure of the local economy, and 322 industry-time dummy variables (Equation (2)). Two variables for each $(h, t)$ observation define correlated preferences. First, we define the industry composition of stock positions of neighboring households (excluding household $h$ itself) at the end of quarter $t-1$. Second, we define the industry composition of stock positions of the household itself at the end of quarter $t-1$. To capture the impact of the structure of the local economy, for each $(h, t, i)$ observation we define two variables: the fraction of market value of companies local to household $h$ in quarter $t$ in industry $i$ and the fraction of the labor force local to household $h$ in quarter $t$ employed in industry $i$. In this framework, estimates of $\beta$ are conservative lower bounds on the contribution of word-of-mouth effects to the overall information diffusion effect. Panel A has three sections, containing estimates for all buys, local buys, and non-local buys, respectively. Within each section, we first show the baseline result. The following row in each section shows the results with the two additional independent variables that seek to capture preferences for industry allocation. The third row in each section of Panel A includes the variables that capture the structure of the local economy. The fourth row in each section features the results of relating the industry composition of a household's investments to both preferences (the neighborhood's and own) and the structure of the local economy. The final analysis, reported in the fifth row in each section, seeks to capture differences among households along unobservable characteristics by running the baseline regression from Equation (2) with the inclusion of household-level fixed effects. Panels B and C show results of replicating the key analyses from Panel A on two subsamples of households. Specifically, we sort households into two types according to the extent to which their household portfolio allocations at the industry level conform to those of their neighbors; the metric we use is the average absolute deviation in industry portfolio shares between a household and its neighborhood. 

Table XI: Information Diffusion, Correlated Preferences for Industry Allocation,
and Structure of Local Economy (Continued)

\begin{tabular}{|c|c|c|c|c|c|c|c|}
\hline \multirow[b]{2}{*}{ Buys } & \multicolumn{5}{|c|}{ Composition of... } & \multirow[b]{2}{*}{$R^{2}$} & \multirow[b]{2}{*}{ \#obs. } \\
\hline & $\begin{array}{c}\text { Buys of } H H s \\
\leq 50 \text { miles }\end{array}$ & $\begin{array}{l}\text { Positions of } H H s \\
\leq 50 \text { miles }\end{array}$ & $\begin{array}{l}\text { Positions of } \\
\text { this HH }\end{array}$ & $\begin{aligned} & \text { Firms } \\
\leq & 50 \text { miles }\end{aligned}$ & $\begin{aligned} & \text { Workers } \\
\leq & 50 \text { miles }\end{aligned}$ & & \\
\hline \multicolumn{8}{|c|}{ Panel A: All Households } \\
\hline$\overline{A 11}$ & $\begin{array}{l}19.9^{* * *} \\
(0.4)\end{array}$ & & & & & 0.134 & $1,786,666$ \\
\hline All & $\begin{array}{l}9.8^{* * *} \\
(0.4)\end{array}$ & $\begin{array}{l}16.5^{* * *} \\
(0.5)\end{array}$ & $\begin{array}{l}32.5^{* * *} \\
(0.2)\end{array}$ & & & 0.204 & $1,786,666$ \\
\hline All & $\begin{array}{l}17.4^{* * *} \\
(0.4)^{2}\end{array}$ & & & $\begin{array}{l}4.8^{* * *} \\
(0.3)\end{array}$ & $\begin{array}{l}4.0^{* * *} \\
(0.3)^{2}\end{array}$ & 0.135 & $1,786,666$ \\
\hline All & $(0.4)^{* * *}$ & $\begin{array}{l}14.5^{* * *} \\
(0.6)\end{array}$ & $\begin{array}{l}32.4^{* * *} \\
(0.2)\end{array}$ & $(0.3)$ & $(0.3)$ & 0.204 & $1,786,666$ \\
\hline $\begin{array}{l}\text { All } \\
\text { (HH Fixed Effects) }\end{array}$ & $(0.5)$ & & & & & 0.323 & $1,786,666$ \\
\hline Local & $\begin{array}{l}128.9^{* * *} \\
(1.7)\end{array}$ & & & & & 0.249 & 265,509 \\
\hline Local & $\begin{array}{l}43.6^{* * *} \\
(1.7)\end{array}$ & $\begin{array}{l}58.8^{* * *} \\
(2.3)\end{array}$ & $\begin{array}{l}47.5^{* * *} \\
(0.5)\end{array}$ & & & 0.417 & 265,509 \\
\hline Local & $\begin{array}{l}85.1^{* * *} \\
(1.8)\end{array}$ & & & $\begin{array}{l}46.9^{* * *} \\
(1.4)^{2}\end{array}$ & $\begin{array}{l}14.2^{* * *} \\
(1.3)\end{array}$ & 0.276 & 265,509 \\
\hline Local & $\begin{array}{l}36.8^{* * *} \\
(1.7)\end{array}$ & $\begin{array}{l}40.1^{* * *} \\
(2.4)^{2}\end{array}$ & $\begin{array}{l}46.2^{* * *} \\
(0.5)\end{array}$ & $\begin{array}{l}18.1^{* * *} \\
(1.2)\end{array}$ & $(1.1)^{5.6^{* * *}}$ & 0.421 & 265,509 \\
\hline $\begin{array}{l}\text { Local } \\
\text { (HH Fixed Effects) }\end{array}$ & $\begin{array}{l}17.7^{* * *} \\
(2.5)^{-1}\end{array}$ & & & & & 0.577 & 265,509 \\
\hline Non-Local & $\begin{array}{l}7.4^{* * *} \\
(0.4)^{2}\end{array}$ & & & & & 0.121 & $1,510,390$ \\
\hline Non-Local & $\begin{array}{l}3.7^{* * *} \\
(0.4)\end{array}$ & $\begin{array}{l}7.2^{* * *} \\
(0.6)^{2}\end{array}$ & $\begin{array}{l}31.2^{* * *} \\
(0.2)\end{array}$ & & & 0.186 & $1,510,390$ \\
\hline Non-Local & $(0.4)^{* * *}$ & & & $\begin{array}{l}0.7^{* * *} \\
(0.3)\end{array}$ & $(0.3)^{* * *}$ & 0.121 & $1,510,390$ \\
\hline Non-Local & $(0.4)$ & $(0.6)^{* * *}$ & $\begin{array}{l}31.2^{* * *} \\
(0.2)\end{array}$ & $\begin{array}{r}-0.1 \\
(0.3)\end{array}$ & $\begin{array}{l}0.8^{* * *} \\
(0.3)\end{array}$ & 0.186 & $1,510,390$ \\
\hline $\begin{array}{l}\text { Non-Local } \\
\text { (HH Fixed Effects) }\end{array}$ & $(0.5)^{2.4^{* * *}}$ & & & & & 0.305 & $1,510,390$ \\
\hline
\end{tabular}

${ }^{* * *},{ }^{* *},{ }^{*}$ denote significance at the 1 percent, 5 percent, and 10 percent levels, respectively. 
Table XI: Information Diffusion, Correlated Preferences for Industry Allocation, and Structure of Local Economy (Continued)

\begin{tabular}{|c|c|c|c|c|c|c|c|}
\hline \multirow[b]{2}{*}{ Buys } & \multicolumn{5}{|c|}{ Composition of... } & \multirow[b]{2}{*}{$R^{2}$} & \multirow[b]{2}{*}{ \#obs. } \\
\hline & $\begin{array}{l}\text { Buys of HHs } \\
\leq 50 \text { miles }\end{array}$ & $\begin{array}{l}\text { Positions of HHs } \\
\leq 50 \text { miles }\end{array}$ & $\begin{array}{l}\text { Positions of } \\
\text { this HH }\end{array}$ & $\begin{aligned} & \text { Firms } \\
\leq & 50 \text { miles }\end{aligned}$ & $\begin{aligned} & \text { Workers } \\
& \leq 50 \text { miles } \\
&\end{aligned}$ & & \\
\hline \multicolumn{8}{|c|}{$\begin{array}{c}\text { Panel B: Similar HH Portfolios (Average Absolute Deviation in Industry Positions from HHs } \\
\text { within } 50 \text { miles is in Bottom Quartile) }\end{array}$} \\
\hline$\overline{\text { All }}$ & $\begin{array}{l}30.0^{* * *} \\
(0.8)\end{array}$ & & & & & 0.205 & 446,670 \\
\hline All & $\begin{array}{l}10.3^{* * *} \\
(0.8)\end{array}$ & $\left(17.5^{* * *}\right.$ & $\begin{array}{l}35.9^{* * *} \\
(0.5)\end{array}$ & & & 0.245 & 446,670 \\
\hline All & $(0.8)^{* * *}$ & $\begin{array}{l}15.5^{* * *} \\
(1.3)^{-1}\end{array}$ & $\begin{array}{l}35.7^{* * *} \\
(0.5)\end{array}$ & $(0.6)^{2.1 * *}$ & $\begin{array}{l}2.0^{* * *} \\
(0.6)\end{array}$ & 0.245 & 446,670 \\
\hline Local & $\begin{array}{l}148.6^{* * *} \\
(4.2)\end{array}$ & & & & & 0.543 & 66,390 \\
\hline Local $^{+}$ & $\begin{array}{l}53.7^{* * *} \\
(4.8)\end{array}$ & $\begin{array}{l}66.8^{* * *} \\
(6.4)\end{array}$ & $\begin{array}{l}40.1^{* * * *} \\
(1.7)^{2}\end{array}$ & & & 0.586 & 66,390 \\
\hline Local $^{+}$ & $\begin{array}{l}46.2^{* * *} \\
(4.8)\end{array}$ & $\begin{array}{l}53.3^{* * *} \\
(6.9)\end{array}$ & $\begin{array}{l}39.2^{* * *} \\
(1.7)\end{array}$ & $\begin{array}{r}1.6 \\
(3.3)\end{array}$ & $\begin{array}{l}16.6^{* * *} \\
(2.8)\end{array}$ & 0.587 & 66,390 \\
\hline Non-Local & $\begin{array}{l}14.9^{* * *} \\
(0.8)^{3}\end{array}$ & & & & & 0.173 & 377,608 \\
\hline Non-Local $^{+}$ & $\begin{array}{l}3.9^{* * *} \\
(0.8)\end{array}$ & $(1.3)^{\text {(1.** }}$ & $\begin{array}{l}33.6^{* * *} \\
(0.5)\end{array}$ & & & 0.207 & 377,608 \\
\hline Non-Local $^{+}$ & $\begin{array}{l}3.9^{* * *} \\
(0.8)\end{array}$ & $(1.3)^{9 . * *}$ & $\begin{array}{l}33.6^{* * *} \\
(0.5)\end{array}$ & $\begin{array}{r}0.3 \\
(0.6)\end{array}$ & $\begin{array}{r}0.0 \\
(0.6)\end{array}$ & 0.207 & 377,608 \\
\hline
\end{tabular}

Panel C: Disparate HH Portfolios (Average Absolute Deviation in Industry Positions from HHs within 50 miles is in Top Quartile)

\begin{tabular}{|c|c|c|c|c|c|c|c|}
\hline$\overline{\text { All }}$ & $\begin{array}{l}4.5^{\text {**** }} \\
(0.7)\end{array}$ & & & & & 0.067 & 446,670 \\
\hline All & ${ }^{6.4^{* * *}}{ }^{(0.7)}$ & ${ }^{7.2^{* * *}}$ & $\begin{array}{l}27.8^{* * *} \\
(0.3)\end{array}$ & & & 0.143 & 446,670 \\
\hline All & $\begin{array}{l}5.7^{* * * *} \\
(0.7)\end{array}$ & $\begin{array}{l}5.7^{* * *} \\
(0.9)\end{array}$ & $\begin{array}{l}27.8^{* * *} \\
(0.3)\end{array}$ & $\begin{array}{l}2.2^{* * *} \\
(0.5)\end{array}$ & $\begin{array}{l}2.0^{* * *} \\
(0.5)\end{array}$ & 0.143 & 446,670 \\
\hline Local & $\begin{array}{l}60.6^{* * *} \\
(3.2)\end{array}$ & & & & & 0.064 & 66,390 \\
\hline Local $^{+}$ & $\begin{array}{l}40.6^{* * *} \\
(3.1)\end{array}$ & $\begin{array}{l}52.4^{* * * *} \\
(4.1)\end{array}$ & $\begin{array}{l}45.7^{\text {*** }} \\
(0.7)\end{array}$ & & & 0.265 & 66,390 \\
\hline Local $^{+}$ & $\begin{array}{l}29.4^{* * *} \\
(3.0)\end{array}$ & $\begin{array}{l}29.1^{\text {**** }} \\
(4.0)\end{array}$ & $\begin{array}{l}43.9^{* * *} \\
(0.8)\end{array}$ & $\begin{array}{l}30.0^{* * *} \\
(2.2)\end{array}$ & $\begin{array}{r}3.4 \\
(2.3)\end{array}$ & 0.275 & 66,390 \\
\hline Non-Local & $\begin{array}{r}0.1 \\
(0.7)\end{array}$ & & & & & 0.063 & 377,608 \\
\hline Non-Local $^{+}$ & ${ }^{3.1^{* * * *}}$ & $(0.9)^{* * *}$ & $\begin{array}{l}27.1^{\text {**** }} \\
(0.3)^{4}\end{array}$ & & & 0.135 & 377,608 \\
\hline Non-Local $^{+}$ & $\begin{array}{l}2.9^{* * *} \\
(0.7)\end{array}$ & $\begin{array}{l}2.0^{\text {** }} \\
(0.9)\end{array}$ & $\begin{array}{l}27.1^{* * *} \\
(0.3)\end{array}$ & $\begin{array}{r}0.1 \\
(0.5)\end{array}$ & $\begin{array}{r}0.8 \\
(0.6)\end{array}$ & 0.135 & 377,608 \\
\hline
\end{tabular}

${ }^{* * *},{ }^{* *},{ }^{*}$ denote significance at the 1 percent, 5 percent, and 10 percent levels, respectively.

${ }^{+}$denotes that the difference in coefficients across the similar and disparate samples is not significant at the one percent level. 
Table XII: Relation Between Word-of-Mouth Effects and Other Diffusion Effects and Future Stock Returns Across Industries

This table presents panel regression results of relating industry-level returns prevailing over the next period to current information diffusion effects, industries' current performance, individual investors' demand for stocks at the industry level, as well industry and quarter effects. The regression at the quarterly horizon (Panel A) is specified as follows (Equation (6)):

$$
R_{q+1, i}=\beta_{W O M}^{N L} W \hat{O} M_{t, i}^{N L}+\beta_{O D}^{N L} O \hat{D}_{t, i}^{N L}+\beta_{R} R_{q, i}+\beta_{B S I} B S I_{t, i}+\sum_{t=1}^{23} \gamma_{t} D_{t}+\sum_{i=1}^{14} \delta_{i} D_{i}+\varepsilon_{t, i}
$$

The first regressor is the quarterly industry-level non-local information diffusion estimate attributed to word-of-mouth effects ("WOM"), the second regressor is the quarterly industry-level non-local information diffusion estimate attributed to other information diffusion effects ("OD"), while the remaining regressors are analogous to those from Table IX. The annual regression (Panel B) differs only in regard to the horizon of future industry-level returns (i.e., the left-hand-side variable) - those returns stretch across the next four quarters.

\begin{tabular}{|c|c|c|c|c|c|c|}
\hline & \multicolumn{3}{|c|}{$\begin{array}{c}\text { Panel A: } \\
\text { Dependent Variable }= \\
\text { Industry Return Over Quarter }{ }_{t+1} \\
\text { (in percent) }\end{array}$} & \multicolumn{3}{|c|}{$\begin{array}{c}\text { Panel B: } \\
\text { Dependent Variable }= \\
\text { Industry Return Over Quarters } s_{t+1} \text { to } t+4 \\
\text { (in percent) }\end{array}$} \\
\hline & (1) & $(2)$ & (3) & (4) & (5) & (6) \\
\hline NON-LOCAL BUY Word-of-Mouth & $\begin{array}{c}0.077^{*} \\
(0.041)\end{array}$ & $\begin{array}{l}0.083^{* *} \\
(0.041)\end{array}$ & $\begin{array}{l}0.083^{* *} \\
(0.041)\end{array}$ & $\begin{array}{c}0.208^{*} \\
(0.118)\end{array}$ & $\begin{array}{l}0.231^{* *} \\
(0.118)\end{array}$ & $\begin{array}{c}0.233^{*} \\
(0.122)\end{array}$ \\
\hline NON-LOCAL BUY Other Diffusion $_{t}$ & $\begin{array}{r}0.050 \\
(0.066)\end{array}$ & $\begin{array}{r}0.060 \\
(0.066)\end{array}$ & $\begin{array}{r}0.059 \\
(0.066)\end{array}$ & $\begin{array}{r}0.041 \\
(0.169)\end{array}$ & $\begin{array}{r}0.080 \\
(0.164)\end{array}$ & $\begin{array}{r}0.092 \\
(0.167)\end{array}$ \\
\hline Return $_{\mathrm{t}}$ & & $\begin{array}{r}0.072 \\
(0.067)\end{array}$ & $\begin{array}{r}0.078 \\
(0.069)\end{array}$ & & $\begin{array}{c}0.298^{* *} \\
(0.147)\end{array}$ & $\begin{array}{r}0.226 \\
(0.157)\end{array}$ \\
\hline Buy-Sell Imbalance $_{t}$ & & & $\begin{array}{r}0.010 \\
(0.026)\end{array}$ & & & $\begin{array}{r}-0.111 \\
(0.085)\end{array}$ \\
\hline Industry effects included? & Yes & Yes & Yes & Yes & Yes & Yes \\
\hline Quarter effects included? & Yes & Yes & Yes & Yes & Yes & Yes \\
\hline $\mathrm{R}^{2}$ & 0.568 & 0.569 & 0.568 & 0.495 & 0.503 & 0.507 \\
\hline \# of observations & 322 & 322 & 322 & 322 & 322 & 322 \\
\hline
\end{tabular}

${ }^{* * * * * *},{ }^{*}$ denote significance at the 1 percent, 5 percent, and 10 percent levels, respectively. 


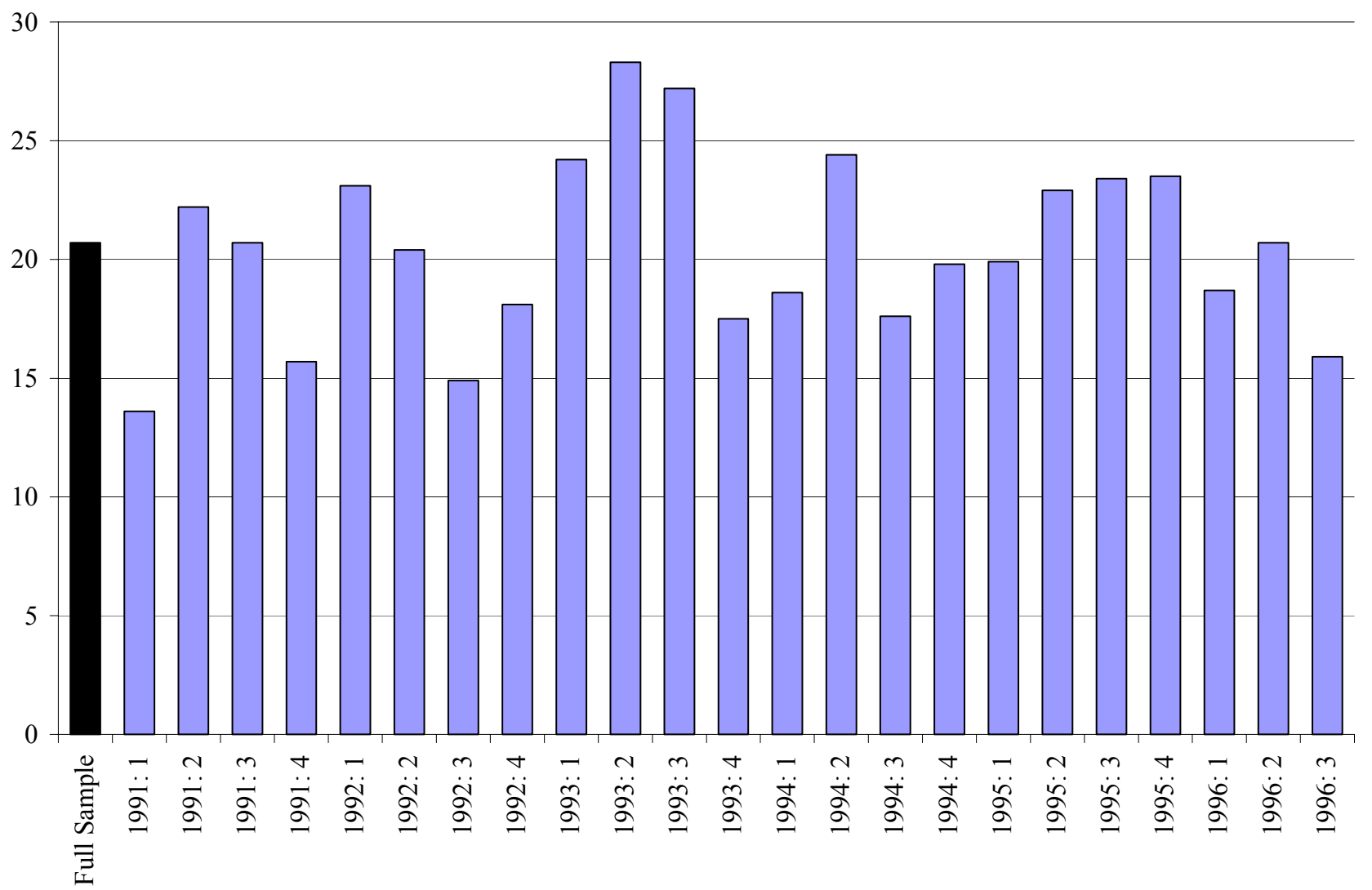

Figure 1: Information Diffusion and Common Stock Purchases, Regression of Composition of Household Stock Purchases Upon Composition of Local Stock Purchases (in percent). The $\beta$ denoted with a black bar is based on the specification over the full sample period from Equation 2:

$$
f_{h, t, i}=\beta F_{-h, t, i}^{50}+\sum_{t=1}^{23} \sum_{i=1}^{14} \gamma_{t, i} D_{t, i}+\varepsilon_{h, t, i} .
$$

The $\beta \mathrm{s}$ denoted with gray bars are based on a variant of the specification from Equation 2, carried out for each quarter $t$ :

$$
f_{h, i}=\beta F_{-h, i}^{50}+\sum_{i=1}^{14} \gamma_{i} D_{i}+\varepsilon_{h, i} .
$$

For the full sample, the estimate of $20.7 \%$ suggests that a 10 percentage point change in the neighbors' allocation of purchases in an industry is associated with a nearly 2.1 percentage point change in the household's own allocation of purchases in the industry. 


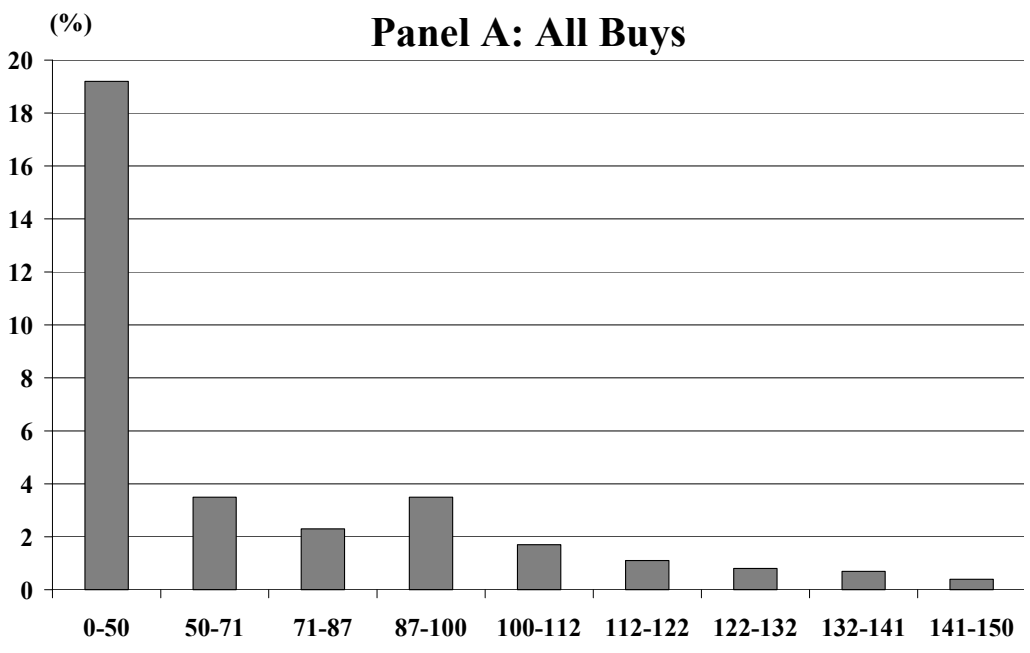

radius [miles]

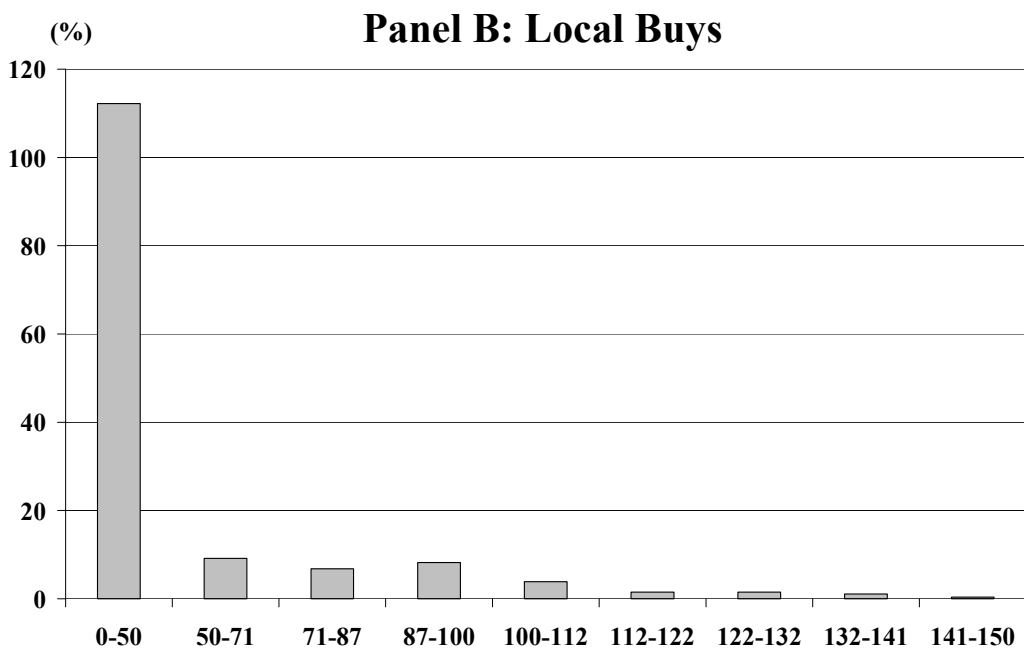

radius [miles]

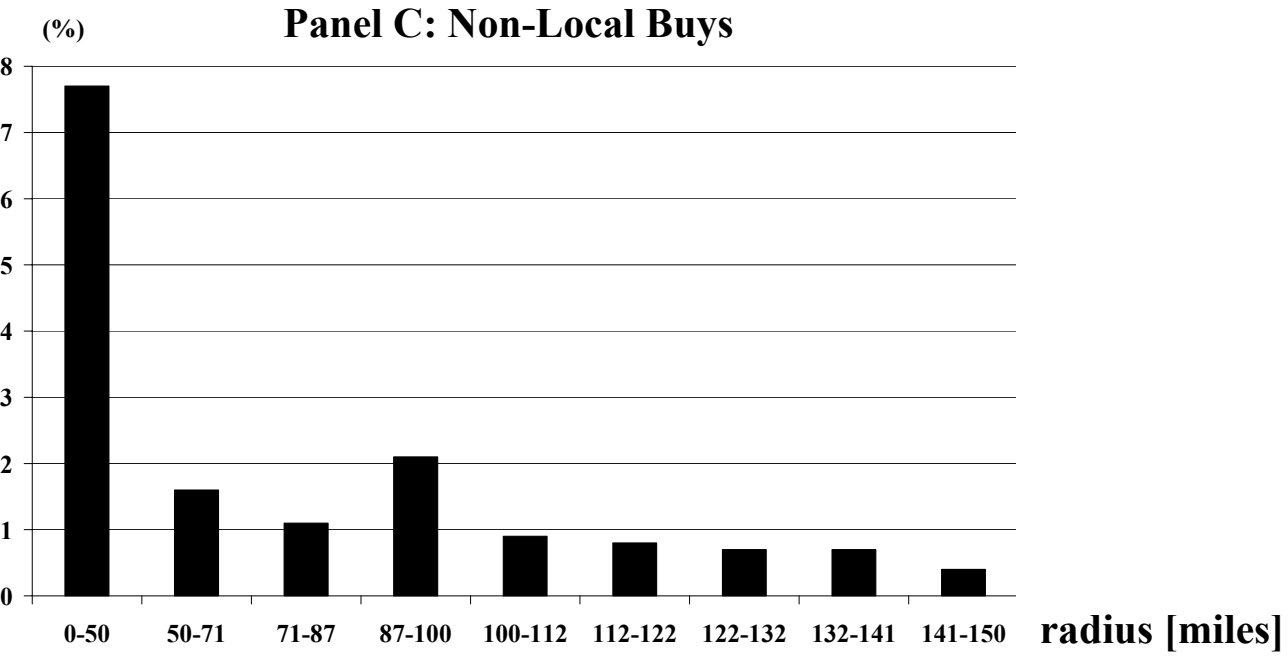

Figure 2: Dissipation of Information Diffusion. The figure illustrates dissipation of information diffusion effects with distance from the household. Regions surrounding the household at increasingly larger distances have the same geographic area $\left(50^{2} \pi=7,854\right.$ square miles). The regression specification is similar to Equation (2), except, instead of having one information diffusion regressor, the specification now has nine-one for each geographic area. 


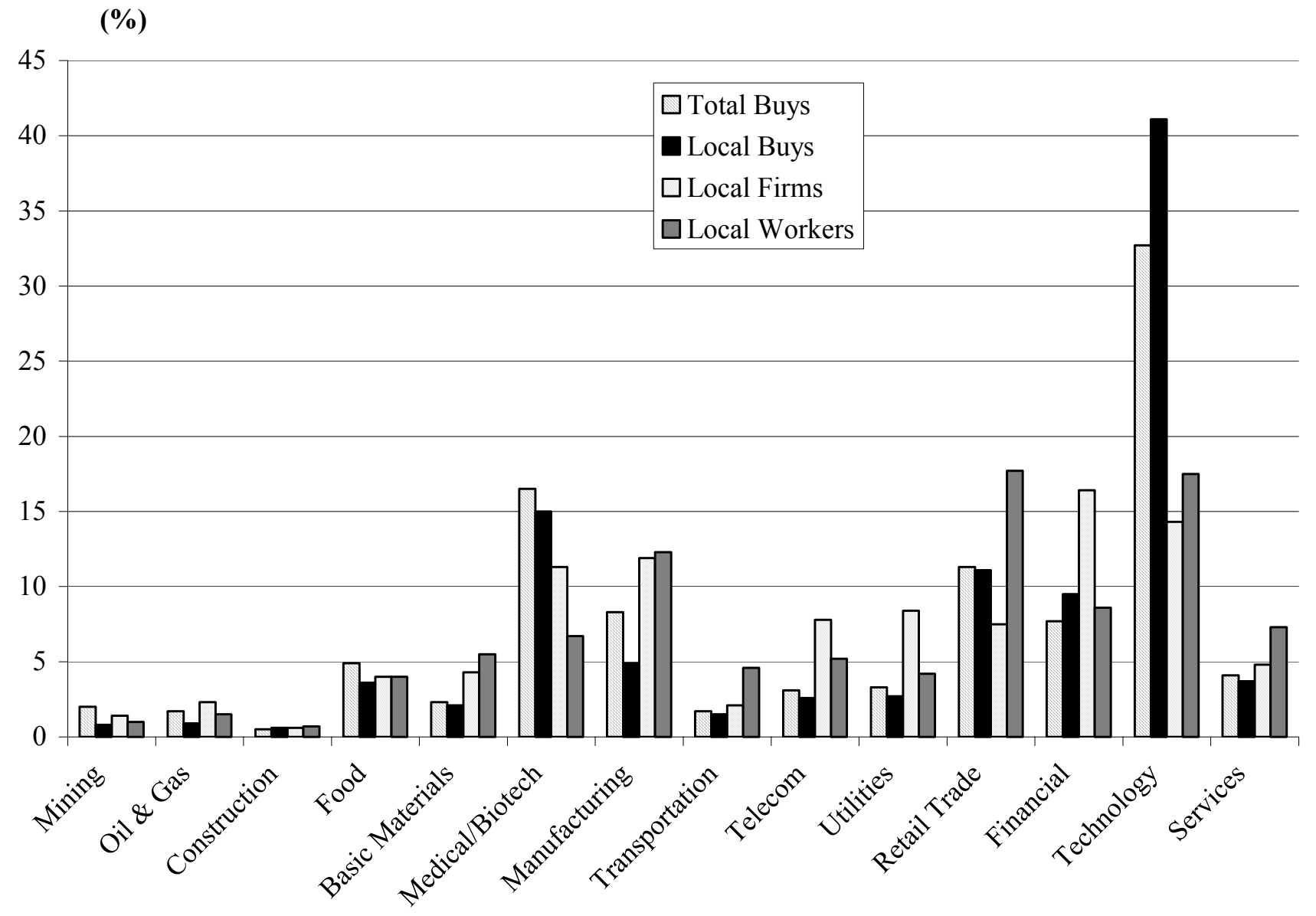

Figure 3: Average Industry Composition of Quarterly Purchases, Firms Local to the Household (within 50 miles), and Corporate Workers Local to the Household, Pooled Over the Entire Sample Period 1/1991 - 9/1996. 
(\%)

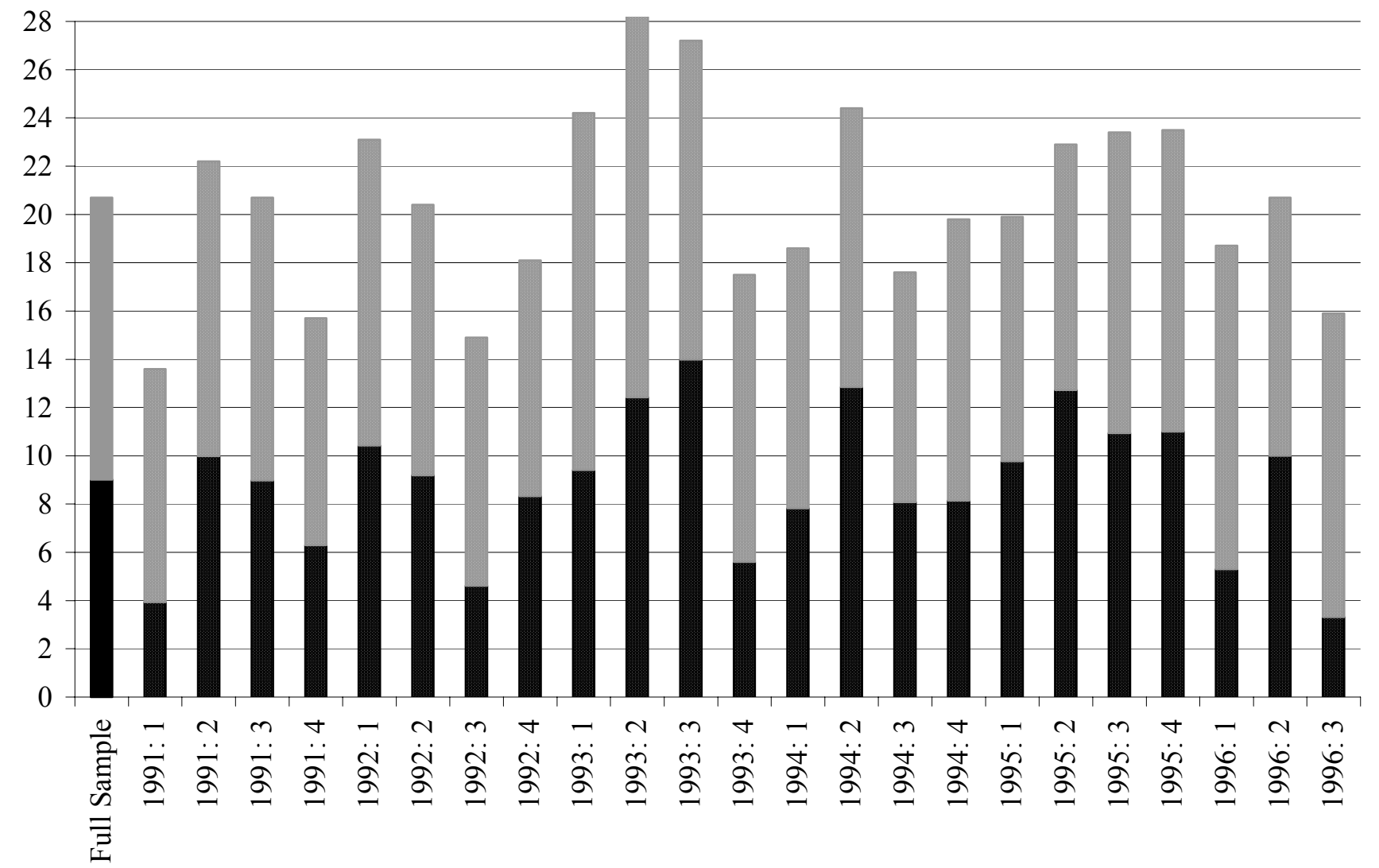

Figure 4: Word-of-Mouth Effects and Overall Information Diffusion Effects, All Buys. The $\beta$ s denoted with gray bars replicate the bars from Figure 1: they reflect the overall information dissemination effects. The $\beta$ s denoted with black bars reflect conservative estimates of the wordof-mouth effect: they come from regressions analogous to those fitted to produce Figure 1 with added controls for common preferences and the structure of the local economy. Full bars pertain to the full sample (pooled observations from 1991:1 to 1996:3), whereas the dotted bars pertain to estimates that come from quarterly regressions. For the full sample, the overall diffusion effect estimate of $20.7 \%$ suggests that a 10 percentage point change in the neighbors' allocation of purchases in an industry is associated with a nearly 2.1 percentage point change in the household's own allocation of purchases in the industry. 